\title{
Mudança estrutural e crescimento sob restrição externa na economia brasileira: uma análise empírica do período 1962-2006 com considerações sobre o II PND *
}

\author{
Raphael Rocha Gouvêa ** \\ Gilberto Tadeu Lima ${ }^{* * *}$
}

\begin{abstract}
Resumo
Este artigo reporta exercícios empíricos que, ao explorar implicações da Lei de Thirlwall Multissetorial, contribuem para a compreensão da relação entre mudança estrutural, restrição externa e crescimento econômico na economia brasileira no período 1962-2006. Dadas a natureza setorial desse exercício empírico e sua conexão com a literatura historiográfica sobre o II Plano Nacional de Desenvolvimento, os resultados foram utilizados para avaliar a contribuição dos setores para a evolução das elasticidades-renda ponderadas das exportações e importações, subsidiando, assim, o debate existente acerca do ajustamento externo promovido entre 1974 e 1984. Os resultados sugerem que a interpretação de Castro (1985), mesmo quando avaliada sob uma métrica diferente daquela utilizada pelo autor, possui fundamento empírico. Esses resultados subsidiam também a qualificação de Fishlow (1986) de que a melhoria na balança comercial em 1983-1984 decorreu mais do comportamento das exportações do que das importações.
\end{abstract}

Palavras-chave: Mudança estrutural; Crescimento econômico; Restrição externa; II PND.

\begin{abstract}
Structural change and economic growth under external constraint in the Brazilian economy: 1962-2006

By exploring the implications of the Multi-Sector Thirlwall's Law, this paper reports empirical exercises that contribute to an understanding of the relationship between structural change, external constraint and economic growth in Brazil in the 1962-2006 period. Given the sectoral nature of these empirical exercises and their connection with the historical literature about the II National Development Plan, the results were used to evaluate each sectors' contribution to the evolution of the weighted income elasticities of exports and imports during the period. These findings provide additional support to the existing debate about the external adjustment promoted between 1974 and 1984. The results suggest that Castro's (1985) interpretation has empirical support, even if evaluated using a different metric than the one used by the author. However, the results also support Fishlow's (1986) qualification that the improvement in the trade balance in 1983-1984 was due to a greater extent to the behavior of exports than to the behavior of imports.
\end{abstract}

* Trabalho recebido em 5 de maio de 2010 e aprovado em 12 de maio de 2012. Os autores agradecem os comentários recebidos de Gabriel Porcile, Frederico Jayme Jr. e dos pareceristas anônimos da revista, isentando-os de qualquer erro remanescente. Os autores agradecem também o apoio financeiro do Centro Internacional Celso Furtado de Políticas para o Desenvolvimento (Raphael Rocha Gouvêa) e do Conselho Nacional de Desenvolvimento Científico e Tecnológico - CNPq (Gilberto Tadeu Lima).

** Técnico de Pesquisa e Planejamento do Ipea (Instituto de Pesquisa Econômica Aplicada), Brasília, DF, Brasil. E-mail: raphael.gouvea@ipea.gov.br.

*** Professor do Departamento de Economia da FEA-USP (Faculdade de Economia, Administração e Contabilidade da Universidade de São Paulo), São Paulo, SP, Brasil. E-mail: giltadeu@usp.br. 
Keywords: Structural change; Economic growth; External constraint; II PND.

JEL E10, F14, F40, O41.

\section{Introdução}

A abordagem do crescimento sob restrição externa à la Thirlwall tem sido utilizada por vários autores para investigar a dinâmica de crescimento de longo prazo de diversas economias. Essa abordagem, de tradição keynesiana e que, portanto, atribui primazia à demanda, identifica a restrição de divisas decorrente da necessidade de equilíbrio de longo prazo do balanço de pagamentos como sendo a restrição mais relevante ao crescimento de um amplo conjunto de países, entre eles o Brasil (Bértola et al., 2002; Jayme Jr., 2007; Carvalho et al., 2008; Carvalho; Lima, 2008, 2009; Britto; McCombie, 2009) ${ }^{1}$. Segundo Thirlwall (1979), se supusermos que os termos de troca são constantes e que deve haver equilíbrio comercial no longo prazo, há uma correspondência entre o crescimento do produto e a razão entre as elasticidades-renda da demanda por exportações e importações. Tal resultado ficou conhecido na literatura como Lei de Thirlwall, doravante LT.

Deve-se destacar, no entanto, que a abordagem do crescimento sob restrição externa à la Thirlwall, apesar de atribuir primazia à demanda, reconhece a importância de atributos em nível de oferta. As diferenças de elasticidades-renda da demanda por importações e exportações entre países - parâmetros que, em última instância, definem a intensidade da restrição - refletem as características de competitividade não preço dos bens e, portanto, a estrutura produtiva (Thirlwall, 1997, p. 383). Nesse contexto, a única maneira consistente de elevar a taxa de crescimento compatível com o equilíbrio externo de um país é a mudança estrutural no sentido de elevar sua elasticidade-renda da demanda por exportações e reduzir sua elasticidade-renda da demanda por importações. Como ressalta o próprio Thirlwall, "voltamos às idéias de Raul Prebisch e à questão da política industrial mais apropriada" (Thirlwall, 2005, p. 69).

A ideia de que a mudança estrutural pode afetar as elasticidades-renda das importações e exportações vem sendo explorada por diversos autores tanto no campo teórico (Setterfield, 1997; McCombie; Roberts, 2002; Palley, 2002) quanto empírico (Bairam, 1997; Thirlwall, 1997; Dutt, 2003; Cimoli et al., 2010). Em termos de mudança estrutural mais amplamente, uma das principais contribuições à teoria do crescimento conduzido pela demanda é a abordagem structural economic dynamics (SED), proposta por Pasinetti (1981, 1993). De acordo com a SED,

(1) Carvalho (2007) identifica cinco grandes linhas de testes empíricos na literatura de crescimento sob restrição externa. Além disso, apresenta uma revisão detalhada da literatura empírica sobre a LT desenvolvida até 2006. Em relação à literatura empírica que utiliza a versão multissetorial, Gouvêa e Lima (2010) realizam testes individuais com dados de séries temporais para quatro países asiáticos e quatro latino-americanos, e Gouvêa e Lima (2013) apresentam evidências a partir de um painel de 90 países no período 1965-1999. 
mudanças na estrutura de produção dos países alteram suas taxas de crescimento e, portanto, diferentes estruturas produtivas implicam diferenças em suas taxas de crescimento. Como destacam Araújo e Lima (2007), enquanto essa conexão entre estrutura produtiva e crescimento é realizada de maneira explícita por Pasinetti (1981, 1993) em um arcabouço multissetorial, embora principalmente em um contexto de economia fechada, a abordagem do crescimento sob restrição externa $a ̀$ la Thirlwall realiza essa conexão em um contexto mais amplo de economia aberta, ainda que somente implicitamente, através da concepção de que a composição das exportações e importações está refletida nas elasticidades-renda agregadas. Desse modo, esses autores derivam uma taxa de crescimento compatível com o equilíbrio externo, análoga à LT, em um arcabouço pasinettiano multissetorial. A Lei de Thirlwall Multissetorial (LTMS), como a denominaram os autores, indica que a taxa de crescimento per capita de um país é diretamente proporcional à taxa de crescimento de suas exportações, sendo que essa proporcionalidade é inversamente (diretamente) relacionada com as elasticidades setoriais da demanda por importações (exportações). As elasticidades setoriais, por sua vez, são ponderadas pela participação de cada setor nas importações e exportações totais, respectivamente.

Uma importante implicação da LTMS é que mudanças na composição da demanda ou da estrutura de produção, que não são refletidas em mudança nas elasticidades, mas refletem uma mudança na participação dos setores nas exportações e importações totais, têm impactos sobre o crescimento de longo prazo. Dadas as elasticidades-renda das importações e exportações, a LT original implica que a taxa de crescimento de um país irá aumentar somente se o crescimento da renda mundial aumentar. Entretanto, na versão multissetorial, um país pode aumentar sua taxa de crescimento, mesmo quando não há alteração na taxa de crescimento da renda mundial, caso melhore a composição setorial de suas exportações/importações.

Este artigo reporta exercícios empíricos que, ao explorar implicações da LTMS, contribuem para a compreensão da relação entre mudança estrutural, restrição externa e crescimento econômico na economia brasileira no período 1962 2006. Cabe deixar claro que não se pretende analisar todas as relações que os determinantes estruturais têm com a dinâmica do crescimento. $\mathrm{O}$ artigo tem o propósito específico de utilizar implicações da LTMS para abordar a mudança estrutural tal como captada pelas elasticidades-renda das importações e exportações - particularmente, as implicações que decorrem de alterações na composição das exportações e importações. Desse modo, busca-se contribuir não somente para a literatura empírica dos modelos de crescimento sob restrição externa e sua relação com a mudança estrutural, mas também para o entendimento de algumas questões relevantes da historiografia econômica do país - particularmente, o II Plano 
Nacional de Desenvolvimento (II PND) - 1974-1979. Sendo assim, a próxima seção resenha trabalhos que avaliaram o II PND em seus diversos aspectos, como, por exemplo, motivações para sua implementação, racionalidade econômica, resultados alcançados e efeitos sobre endividamento externo. Cabe enfatizar que essa resenha não cobre toda a gama de trabalhos sobre o tema. Afinal, não se pretende resolver controvérsias sobre o período, mas, sim, subsidiar, com novos resultados empíricos (baseados em uma versão multissetorial da LT), uma melhor compreensão de determinados aspectos da história econômica do período 19741984. Outro ponto a ser destacado é o fato de que, neste trabalho, foram utilizadas a LT e a LTMS, nas quais o equilíbrio externo é representado pelo equilíbrio da balança comercial, sendo dada primazia, portanto, ao componente estrutural da restrição externa. Ainda que outros trabalhos sobre essa abordagem tenham incorporado fluxos de capital e condições de sustentabilidade do endividamento externo aos modelos, a indisponibilidade de dados desagregados de fluxos de capital não permitiu a incorporação desses aspectos aos exercícios empíricos realizados (mais sobre essa questão será comentado na nota de rodapé $n .3$ ).

Além desta introdução e da seção de revisão sobre o II PND, o artigo está estruturado em outras três seções. Na primeira delas, descrevem-se os dados utilizados, apresentam-se os resultados das estimações das funções de demanda e reportam-se os testes de validade das versões multissetorial e agregada da LT para a economia brasileira no período 1962-2006. Na seção seguinte, os resultados obtidos são utilizados em uma investigação da evolução de elasticidades-renda do comércio exterior decorrente do efeito composição das exportações e das importações da qual resultam novas evidências empíricas sobre o ajustamento externo realizado no período 1974-1984. Por último, são feitas considerações finais.

\section{Revisitando o II PND: uma síntese do debate}

A recessão mundial que se seguiu ao choque do petróleo de 1973 atingiu a economia brasileira em um momento no qual aumentava sua dependência externa. O rápido crescimento durante o "milagre econômico" (1968-1973), período no qual a taxa média de crescimento do produto interno bruto foi de $11,2 \%$ ao ano, intensificou o desequilíbrio entre a capacidade produtiva de bens de consumo e de bens intermediários, o que foi agravado pela quadruplicação dos preços do petróleo. Segundo Simonsen (1978, p. 16, apud Naretto, 1994, p. 9, grifos incluídos), então Ministro da Fazenda do governo Geisel (1974-1979), “diminuir a dependência externa exigiria, naturalmente, a modificação da estrutura industrial do País, com a contenção do crescimento da ponta e a expansão do crescimento da base". Essa também era a visão do Ministro do Planejamento, João Paulo dos Reis Velloso (1978, p. 51, apud Lessa, 1978, p. 42, grifos incluídos), para quem a 
autossuficiência em matérias primas básicas, o aumento da produção de petróleo e a construção de um sólido setor de equipamentos, conjuntamente com a "expansão e diversificação das exportações para financiar com receita própria a maior parcela possível das importações essenciais ao desenvolvimento sem recurso ao endividamento" se faziam estritamente necessários. Segundo esse diagnóstico, a grave situação externa exigia, portanto, um ajuste focalizado não só na substituição de importações de petróleo e insumos em geral, como também a alteração da composição setorial da economia com a finalidade de reduzir importações ou aumentar exportações.

Foi nesse contexto que o governo Geisel lançou, em fins de 1974, o II PND. Este propunha mobilizar a Nação "para, crescendo rapidamente, mas sem superaquecimento, controlar a inflação e manter em razoável equilíbrio o balanço de pagamentos, com alto nível de reservas" (Brasil, 1974, p. 15, grifos incluídos). Ainda que cônscio da dificuldade de manter as taxas de crescimento do período anterior, mas, de certa forma, contagiado pelo otimismo do milagre, o II PND estabelecia como meta uma taxa de crescimento econômico ao ano de $10 \%$ no período 1975-1979 e projetava, para a indústria, crescimento de 12\% a.a. (Brasil, 1974). Em relação ao setor externo, o II PND identificou que a conquista de mercados no exterior havia sido um dos fatores determinantes para o rápido crescimento do quinquênio precedente. Como consequência, "numa perspectiva de crescimento das exportações a taxas anuais um pouco superiores a $20 \%$ e das importações a taxas um pouco menores" (Brasil, 1974, p. 75), há no plano a proposta de dar continuidade à "integração com a economia mundial, para abrir ao País novas fontes de progresso" (Brasil, 1974, p. 19). Portanto, como destacado por Lessa (1978, p. 38), “o II PND reitera a opção pela articulação da economia brasileira com o comércio e o capital exterior".

Segundo Fishlow (1986, p. 517), “o Plano era basicamente uma acomodação a um novo estágio do desenvolvimento industrial, tendo sido preparado independentemente da nova situação internacional'". Desse modo, ainda que não responda exclusivamente à crise do petróleo e à recessão da economia mundial, a proposta de se realizar um ajuste externo não convencional em uma conjuntura econômica adversa contribuiu para a existência de um intenso debate sobre diversos aspectos do plano. Sendo assim, para subsidiar a conexão entre os resultados deste trabalho e algumas das controvérsias que ainda existem acerca do II PND, principalmente em relação à realização ou não de um ajuste estrutural ao problema do balanço de pagamentos, são apresentados, a seguir, alguns trabalhos que podem ser considerados representativos desse debate.

Mesmo "cônscio das inconveniências da escolha de um período do qual a poeira da história" não havia começado "sequer a assentar", Lessa (1978, p. 2) se propôs a realizar uma apreciação do II PND, focalizando a apresentação das metas 
e retórica do plano. Na primeira parte do trabalho, as metas são apresentadas detalhadamente, concluindo o autor que "o núcleo central da nova estratégia" era "integrado por duas diretivas mutuamente articuladas" (Lessa, 1978, p. 19). A primeira consistia em transferir o núcleo dinâmico de certos setores de bens de consumo para a indústria de base. A segunda privilegiava a correção dos desbalanceamentos da organização industrial mediante o fortalecimento do capital privado nacional, "de molde a inicialmente reequilibrar o tripé [empresa estatalmultinacional- privada nacional] para posteriormente constituir sua hegemonia" (Lessa, 1978, p. 19).

Ao analisar a retórica do plano, Lessa (1978) discute as razões políticoeconômicas que, para ele, animaram sua explicitação e implementação. Primeiro, a visão da economia e sociedade como sistemas fechados, da qual o II PND, conjuntamente com "uma situação socioeconômica captada como de máxima eficácia e controle" (p. 85) é produto. Portanto, fica fácil entender "que o II PND não tenha considerado resistências políticas à sua proposta" (p. 85), uma vez que ele é "um exemplo do exercício de autoridade" (p. 77) de um Estado que "exerce como sujeito a vontade política da Nação" (p. 85). Segundo, esse exercício autoritário era justificado pelo critério de eficácia subjacente à "convicção alimentada pela euforia do milagre". Por fim, a ideia de que a crise externa aumentaria o raio de manobra de uma potência emergente como o Brasil. É com base nessa visão que, segundo Lessa (1978, p. 84), surge "o menor plano do mundo - no sentido físico - com o maior programa, em um mundo em crise. Em suas 134 páginas estão contidos todos os programas e recíprocas articulações imagináveis". Para Lessa (1978, p. 90), o regime autoritário falhou em alterar o padrão de industrialização da economia brasileira, já que, "em algum momento, ao longo de 1976, a Estratégia foi submersa, 'envolvida' pelos crescentes problemas do nível tático".

Em artigo que também se preocupa com a questão das motivações para a implementação do plano, assim como de sua racionalidade, Aguirre e Saddi (1997) apontam que o II PND não se mostrava como uma escolha de elevado grau de racionalidade econômica, tal como argumentavam seus executores e defendido por Castro (1985) em trabalho que será apresentado em maiores detalhes adiante. Segundo as autoras, o II PND "foi um projeto cuja racionalidade foi politicamente determinada" (p. 79), pois, uma vez que o Estado brasileiro não possui características exclusivas de um Estado racional legal, no sentido weberiano do termo, este "também tende a adquirir a forma de dominação neopatrimonial" ( $p$. 81). De acordo com as autoras, as características neopatrimoniais que estavam presentes no Estado brasileiro foram explicitadas durante o II PND na medida em que as respostas ao surgimento de obstáculos à execução do plano basearam-se no estabelecimento de uma complexa "cooptação leal" de "novos" e de "velhos" grupos de interesse. $O$ resultado da conjuntura político-econômica foi a 
constituição de uma aliança política formada pelo capital financeiro nacional, pelas grandes empreiteiras e pelo Estado, que buscou ainda apoio em velhas oligarquias regionais. Assim, afirmam as autoras, "a decisão de implementação de um projeto desenvolvimentista, que visava a um último passo para completar o parque industrial brasileiro, fundou-se, de fato, em motivos políticos e não puramente econômicos" (Aguirre; Saddi, 1997, p. 93).

Em resposta ao texto de Aguirre e Saddi (1998), Velloso (1998) procura defender o II PND em relação aos três conjuntos de críticas realizadas. Da perspectiva da fundamentação do plano, segundo Velloso (1998, p. 136-137), para se responder às críticas, deve ser levado em consideração que a "estratégia de 74" não recorreu à recessão, mas abrangeu um ajuste tanto pelo lado da demanda quanto da oferta. Pelo lado da demanda, a atuação consistiu em se diminuir gradualmente o ritmo de crescimento da economia ao mesmo tempo em que se mantinha o sistema de minidesvalorizações como esforço de mudança de preços relativos e se realizavam ações diretas de incentivo às exportações e contenção das importações. Pelo lado da oferta, o grande objetivo foi a transformação da estrutura produtiva por meio dos programas prioritários do II PND, que consistiam em realizar investimentos maciços em energia, insumos básicos e bens de capital. Segundo Velloso (1998, p. 38-139), as dificuldades na execução do plano, como bem documentadas por Lessa (1978), não são suficientes para se sugerir, como o fazem Aguirre e Saddi (1997), que tenha existido uma "nova aliança política" resultante da "cooptação leal" de grupos de interesse. De acordo com o exministro, a execução dos programas prioritários se manteve normal em todos os anos do governo Geisel, não faltando recursos nesses casos. Em relação à crise da década de 1980, que, segundo as autoras, "teve sua origem, grosso modo, com o II PND" (Aguirre; Saddi, 1997, p. 92) devido à estratégia de crescimento com financiamento externo, Velloso (1998, p. 140-142) argumenta que o fator determinante para que a dívida externa se tornasse explosiva foi a opção do novo governo de João Batista Figueiredo de não desacelerar a economia em 1979, evitando, assim, "fazer o necessário ajuste macroeconômico"2.

Fonseca e Monteiro (2008), por sua vez, criticam a contraposição, feita por Aguirre e Saddi (1997), entre racionalidade econômica e racionalidade política como se fossem explicações alternativas. Segundo os autores, "ambas podem ser perfeitamente associadas para a reconstituição das motivações e do significado do II PND, não havendo sustentação na tese que as assume como excludentes" (Fonseca; Monteiro, 2008, p. 32). Nessa visão, portanto, o II PND seria tanto política quanto economicamente determinado, pois a prioridade ao crescimento econômico formulada no plano era entendida como indispensável para o projeto de distensão e legitimação política do regime. Além disso, os autores defendem a

(2) No texto de Velloso (1998) não fica claro porque o autor acreditava ser necessário realizar o ajuste macroeconômico em 1979 e não em 1974. 
racionalidade econômica do plano, uma vez que possuía "um diagnóstico da economia brasileira, explicitava seus impasses estruturais e conjunturais e, a partir deles, fundamentava a necessidade de executar um conjunto de investimentos" (2008, p. 45).

O diagnóstico feito por Balassa (1979) para o período 1974-1979 diferiu bastante daquele realizado pelos defensores do plano. Para o autor, o objetivo de promover uma desaceleração gradual da economia, enquanto se tomavam medidas para realizar o ajuste estrutural de longo prazo, não foi seguido de maneira consistente. A política adotada teve, na verdade, características stop-and-go, sendo condicionada conjuntamente por indicadores de curto prazo, principalmente emprego e inflação, e por preocupações políticas. De acordo com Balassa (1979, p. 1034), ao invés da adoção de políticas macroeconômicas de contenção da absorção doméstica, as principais políticas colocadas em prática para ajustar o balanço de pagamentos foram proteções às importações, subsídios às exportações e incentivo ao financiamento externo. Analisando as taxas de crescimento do período, média de $6,8 \%$ a.a., tende-se a julgar as políticas adotadas como bem-sucedidas. Entretanto, para Balassa (1979), devem ser analisadas também as implicações que esse padrão de crescimento deixava em termos de sistema de incentivos e proteção ineficiente, que resultaram em maior taxa de inflação, queda de produtividade e elevado grau de endividamento. Some-se a isso, ainda segundo Balassa (1979), a filosofia de substituição de importações "a qualquer custo" materializada na adoção de projetos de investimento que não passavam por análises rigorosas de viabilidade econômica e na discricionariedade na escolha dos beneficiados.

Fishlow (1986) também apresenta uma análise bastante crítica do II PND. Segundo o autor, "os exercícios que se abstraem da economia política do Brasil, com suas receitas orientadas para fora no sentido de atingir um ajustamento eficiente" são bastante simplistas, pois dão pouca "atenção a importantes características estruturais da economia, que impedem a efetivação dos resultados de tal estratégia" (p. 508). Segundo o autor, o crescimento econômico durante o milagre foi beneficiado pela existência de ampla capacidade ociosa herdada do período anterior (1964-1967), o que permitiu altas taxas de crescimento do produto com taxas de investimento e poupança doméstica relativamente baixas. Com o esgotamento da capacidade ociosa, para sustentar uma taxa de crescimento anual de $10 \%$, seria necessário elevar a taxa de poupança nacional em pelo menos $4 \%$, o que conflitava com o incentivo ao consumo de bens duráveis, que tinha sido característica importante do milagre. Adicionalmente, cerca de $80 \%$ das necessidades energéticas do país dependiam de petróleo importado, o que, com a elevação dos preços em 1973, implicava em uma ameaça ao crescimento devido à necessidade de se reduzir importações de equipamentos e insumos intermediários para equilibrar o balanço de pagamentos. Ao mesmo tempo, o novo governo 
almejava iniciar o projeto de institucionalização política do regime instalado em 1964, tornando a realização de um ajuste recessivo incompatível com o momento político. Para Fishlow (1984, p. 511), "respondendo com intensidade variável a essas condições econômicas iniciais e aos objetivos políticos da administração, a política econômica do governo Geisel desdobrou-se em três fases distintas".

A primeira consistiu na aplicação de políticas monetária e fiscal ortodoxas em 1974 com o objetivo de desaquecer a economia. As políticas restritivas não foram capazes de, no curto prazo, desacelerar a inflação e, ainda, provocaram queda da atividade industrial e falências no setor financeiro. Além disso, momentos de incerteza política se seguiram à derrota da ARENA nas eleições de 1974 para o Senado, tornando medidas impopulares pouco adequadas ao contexto político. Portanto, essa primeira fase logo foi substituída pela estratégia agressiva de desenvolvimento, consubstanciada no II PND, que buscava atingir o duplo objetivo de sustentar taxas elevadas de crescimento e promover o ajustamento ao choque do petróleo. Para Fishlow (1986), a viabilidade da estratégia estava assegurada por dois motivos: a indexação generalizada permitiu o convívio com taxas de inflação mais elevadas, e o financiamento externo, ao não exigir grandes aumentos da poupança doméstica, compatibilizou as ambiciosas metas de crescimento e elevação do consumo.

A rejeição de uma resposta ortodoxa que implicaria em promover uma maxidesvalorização do câmbio com o intuito de reduzir a absorção doméstica por meio da redução da renda real e estimular a produção de exportáveis e de substitutos de importações baseava-se na crença de que as alterações dos preços levariam a custos maiores, com a indexação provocando uma inflação generalizada, e não a realocação da produção. Desse modo, de acordo com Fishlow (1986, p. 519-524), foi natural a preferência por uma política mais direta de substituição de importações, com preocupação em incentivar as exportações, baseada em incentivos governamentais. O problema, segundo o autor, era que a substituição de importações em um contexto de inexistência de capacidade ociosa seria demasiado intensiva em importações para provocar a melhora do balanço de pagamentos no curto prazo. Também no longo prazo, a estratégia apresentava-se limitada, uma vez que os projetos específicos não eram analisados sob a ótica de suas relações custo-benefício. Além disso, estava implícito, na estratégia, um crescente papel a ser desempenhado pelo setor público. Entretanto, este se defrontava com a incapacidade de financiar seus projetos à medida que resistia à elevação dos impostos e o setor privado buscava maiores transferências para compensar os controles de preços. "O problema brasileiro era, no fundo, o de um Estado fraco (e não forte, como parecia)” (Fishlow, 1986, p. 523).

A terceira fase da política econômica do governo Geisel, denominada por Fishlow (1986) de "tapa buracos", iniciou-se em meados de 1976 e durou até o fim 
desse governo, sendo caracterizada por uma moderada contenção. A elevação progressiva das taxas de juros reais cumpria os objetivos de desencorajar o consumo e estimular tomadores domésticos a recorrerem ao financiamento externo. Mesmo com aumento dos juros, havia expansão da base monetária, uma vez que as entradas de capital superavam a necessidade de financiamento do déficit em conta corrente e as divisas excedentes eram utilizadas para acumular reservas. Devido à natureza de quase-moeda dos títulos públicos, a acumulação de reservas, mesmo quando esterilizadas, expandia a base monetária e os depósitos nos bancos comerciais. O aumento da taxa de juros contribuiu também para aumentar a demanda por crédito subsidiado por parte dos produtores, e os controles de preços administrativos resultaram em déficits ainda maiores das estatais, financiados por empréstimos externos. De acordo com Fishlow (1986, p. 526), nesse contexto, "proliferavam os controles, em lugar das prioridades". O crescimento dos subsídios estimulou a busca por benefícios pelo setor privado, fazendo diminuir a transparência e a análise puramente econômica na elaboração do empenho dos recursos. A situação do setor externo deteriorava-se com velocidade. A política cambial se limitava a acompanhar a inflação relativa, rejeitando desvalorizações maiores devido à expectativa de repasse a preços e salários. As exportações, ainda que continuassem a crescer, perdiam competitividade. Para piorar, a dívida externa cresceu aproximadamente $28 \%$ a.a na média do período 1973-1978, deteriorando a relação dívida externa/exportações. Para Fishlow (1986, p. 526) "tais resultados indicavam dificuldades mais à frente".

Essa visão recebeu recentemente suporte empírico em Santos e Colistete (2009), em que é utilizada a metodologia de Vetores Autorregressivos e de Decomposição da Variância do Erro de Previsão para avaliar quantitativamente três questões gerais do período identificadas a partir da literatura existente. A primeira refere-se à influência de fatores internos e externos nas decisões econômicas do período. Segundo os autores, "os resultados da análise quantitativa indicam que os choques externos tiveram influência modesta nas oscilações das despesas governamentais" (Santos; Colistete, 2000, p. 25). Além disso, a própria despesa do governo apresentou-se como a variável que mais influenciou a determinação dos gastos públicos, mesmo quando comparada a outras variáveis internas, o que pode indicar que motivações políticas foram mais importantes do que os critérios econômicos para a implementação do II PND. A segunda contribuição do artigo diz respeito à avaliação dos impactos do plano sobre o desempenho macroeconômico nas décadas subsequentes. De acordo com os resultados, a própria dívida externa, as despesas do governo e a substituição de importações foram as variáveis que exerceram maior efeito sobre o endividamento externo no período. Dessa maneira, segundo Santos e Colistete (2009, p. 26), o II PND contribuiu, de forma decisiva, para os graves desequilíbrios das décadas seguintes. As evidências sugerem também que tanto a substituição de importações quanto as 
despesas do governo colaboraram para a promoção das exportações principalmente nos primeiros anos. Uma vez que a geração de divisas tornou-se imperativa para a manutenção das importações e pagamento do crescente serviço da dívida, o endividamento externo passou a ser progressivamente um dos principais condicionantes da promoção das exportações; ainda assim, de acordo com os autores, parece ter sido priorizada a substituição de importações. Santos e Colistete (2009, p. 27) defendem que os resultados encontrados, ao sugerirem que o endividamento externo durante o II PND contribuiu significativamente para os desequilíbrios dos anos subsequentes, "levantam sérias dúvidas a respeito da consistência do Plano enquanto estratégia de ajuste estrutural e de desenvolvimento sustentado de longo prazo",

Para finalizar esta resenha de trabalhos sobre o II PND, será apresentada a tese de Castro (1985) "Ajustamento x transformação: a economia brasileira de 1974 a 1984”. A opção de concluir essa breve discussão com a apresentação desse trabalho baseia-se no fato de ser considerado, muito provavelmente, a mais influente interpretação do período 1974-1984 e porque os exercícios empíricos apresentados nas próximas seções dialogam de maneira mais direta, ainda que não exclusiva, com essa interpretação. Isso porque, dadas as implicações setoriais em termos de crescimento sob restrição externa da LTMS, esta se qualifica naturalmente para fornecer evidências empíricas relevantes para uma análise da interpretação de Castro (1985). Vale deixar claro, entretanto, que os exercícios empíricos não pretendem testar essa interpretação, mas, sim, fornecer evidências que subsidiem uma melhor compreensão de seu alcance.

Castro (1985) inicia sua análise argumentando que no período de dois anos, de 1983 a 1984, houve uma grande alteração nas relações da economia brasileira com o exterior. De um relativo equilíbrio na balança comercial em 1982, o país se encontrava, ao fim de 1984, em uma situação na qual o valor de suas exportações equivalia a quase o dobro do valor de suas importações, o que contribuiu significativamente para redução do déficit em transações correntes. $O$ autor questiona, entretanto, a visão de que foram as políticas de ajustamento colocadas em prática entre 1983-1984 por Delfim Netto, então Ministro da Fazenda do governo Figueiredo, as responsáveis por esse desempenho comercial. Por um lado,

(3) Na derivação tanto da LT original como da LTMS, o equilíbrio externo é representado pelo equilíbrio na balança comercial, primazia sendo dada, portanto, ao componente de competitividade estrutural da restrição externa. A elaboração de Thirlwall e Hussain (1982), pioneira na incorporação de fluxos de capital ao modelo de Thirlwall (1979), foi estendida teórica e empiricamente em McCombie e Thirlwall (1997), Moreno-Brid (1998-99) e Barbosa-Filho (2001), especialmente pela consideração explícita de condições de sustentabilidade do endividamento externo. Como este artigo estimou a LT original, seus resultados não subsidiam diretamente o debate sobre o papel do II PND nos desequilíbrios futuros em termos de endividamento. Além disso, como o objetivo central do artigo é explorar implicações da versão multissetorial da LT em termos de evolução da intensidade da restrição externa no Brasil, a indisponibilidade de dados desagregados de fluxos de capital não permitiu sua incorporação aos exercícios empíricos correspondentes. 
essa política procurou reduzir o dispêndio interno por meio da redução do déficit público, da restrição de crédito e da alteração da política salarial que visou comprimir os salários e, consequentemente, reduzir a demanda de bens de consumo. Por outro, realizou-se uma maxidesvalorização cambial, e reajustaram-se os preços de energia elétrica e de alguns derivados do petróleo de forma a promover uma reorientação do gasto. Para Castro (1985, p. 17-24), porém, o ajuste que veio a ocorrer não correspondeu ao que seria esperado como resultado dessas medidas; o que de fato se verificou foi o retorno das exportações à sua tendência de longo prazo e queda drástica das importações no período. A queda das importações pode ser explicada, segundo o autor, devido ao comportamento distinto de dois grupos de produtos. No primeiro grupo, no qual se encontram os produtos dos setores apoiados pelo II PND, as importações caem rapidamente, sendo que, em alguns casos, essa queda é seguida pelo início das exportações. No segundo grupo, composto por produtos de setores que não foram objeto dos grandes programas, as importações seguiram o comportamento dos agregados macroeconômicos, tais como nível geral de atividades, investimento e montante de exportações. Desse modo, conclui Castro (1985) que, para entender esse processo de ajuste do balanço de pagamentos, "temos de remontar à traumática experiência em que se viu o país metido, no ano de 1974, e à resposta a ela dada pelo governo brasileiro" (p. 26), uma vez que "em resposta à crise que eclode em 1974, a economia brasileira foi levada a ingressar num longo período de "marcha forçada"” (p. 8).

Para Castro (1985), segundo a sabedoria econômica convencional da época, o país teria duas opções após a crise do petróleo: financiamento ou ajustamento. A opção pelo ajustamento estava condenada, desde o princípio, tanto por aspectos econômicos quanto políticos, tal como apontado por Fishlow (1986) e apresentado em parágrafo anterior. Entretanto, de acordo com Castro (1985, p. 33), a visão de que "ao evitar o ajustamento e recorrer a empréstimos externos, o país teria escolhido o financiamento e, com ele, adiado a solução de problemas" é equivocada, uma vez que, "longe de evitar problemas, a opção brasileira foi no sentido de atacá-los pela raiz". Porém, "as soluções (...) ficavam adiadas, dado o prazo tecnicamente requerido pela maturação dos investimentos" (p. 40). A opção de atuar preferencialmente sobre a formação de capital com o intuito de substituir importações e abrir novas frentes de exportações resultaria em uma sustentação da conjuntura, assegurando espaço necessário para a absorção do surto anterior de investimentos (a "safra do milagre"), e na modificação, a longo prazo, da estrutura produtiva. Assim, na visão do autor, "enquanto reforma da estrutura produtiva, e mudança da inserção do país no mercado mundial, o programa só seria realizado nos primeiros anos da atual década - quando, aliás, se revelaria mais necessário que nunca" (p. 40).

Para defender seu argumento, Castro (1985, p. 57-61) apresenta uma metodologia para avaliar os ganhos de divisas decorrentes dos grandes programas 
do II PND. Essa metodologia se baseia no cálculo dos dólares poupados mediante substituição de importações e via exportações adicionais setor por setor. O primeiro passo do cálculo consistiu em comparar, ano a ano, o consumo interno de cada grupo de produto pertencente aos setores prioritários do II PND com o nível médio de sua produção em 1979-1980. A diferença entre os dois valores fornece, segundo o autor, uma estimativa do volume de importações líquidas virtuais que teria sido necessário se não entrasse em operação a capacidade produtiva adicional. Três hipóteses são fundamentais para esse cálculo: primeiro, que, no período base, a capacidade instalada encontrava-se em plena utilização; segundo, que todo acréscimo de capacidade posterior a 1980 provém dos programas setoriais; e, terceiro, caso não fosse atendido por produção doméstica, o suprimento desses produtos teria sido feito por meio de importações. Os resultados são apresentados na Tabela 1, a partir da qual se pode concluir, de acordo com Castro (1985), que, para conseguir o saldo comercial obtido em 1983 e 1984, sem contar com os ganhos advindos dos programas setoriais, seria necessário comprimir adicionalmente o gasto líquido de divisas em 4,9 e 7,4 bilhões de dólares em 1983 e 1984, respectivamente ${ }^{4}$.

Tabela 1

Ganho de divisas derivados dos programas setoriais (US\$ milhões)

\begin{tabular}{cccccccc}
\hline Ano & Petróleo & $\begin{array}{c}\text { Metais Não } \\
\text { Ferrosos }\end{array}$ & $\begin{array}{c}\text { Papel e } \\
\text { Celulose }\end{array}$ & $\begin{array}{c}\text { Produtos } \\
\text { Siderúrgicos }\end{array}$ & Fertilizantes & $\begin{array}{c}\text { Produtos } \\
\text { Químicos }\end{array}$ & Total \\
\hline 1981 & 1.052 & 22 & 90 & 149 & 354 & 1.029 & 2.696 \\
1982 & 1.903 & 139 & 170 & 79 & 218 & 1.210 & 3.719 \\
1983 & 2.351 & 366 & 188 & 363 & 308 & 1.308 & 4.884 \\
1984 & 4.404 & 353 & 378 & 636 & 325 & 1.307 & 7.403 \\
\hline
\end{tabular}

Fonte: Castro (198, p. 59)

Fishlow (1986, p. 540-542) apresenta três deficiências da defesa da estratégia de ajustamento pela substituição de importações apresentada por Castro (1985). Primeiro, o cálculo da poupança bruta de divisas não leva em consideração a questão dos investimentos realizados e os custos macroeconômicos do desequilíbrio que esses investimentos provocaram. Segundo, a atribuição de todas as mudanças após 1980 aos investimentos planejados durante o II PND não seria justificável. Por fim, o argumento de que a fonte primordial dos superávits de 1983 e 1984 nos setores programados foi a substituição de importações, e só secundariamente a promoção de exportações, não se sustenta, uma vez que, entre 1980 e 1984, o crescimento das exportações foi uma fonte mais importante de

(4) Castro (1985) somente apresenta o cálculo do ganho de divisas do setor de bens de capital no apêndice do livro, sendo que os resultados sugerem ganhos de 1,7 e 2,2 bilhões de dólares em 1983 e 1984, respectivamente. Segundo o autor, supor plena utilização da capacidade em 1979-1980 para esse setor não seria adequado, por isso, o cálculo, nesse caso, foi tratado à parte. 
crescimento industrial do que a substituição de importações. Portanto, para Fishlow (1986, p. 541), “o crescimento das exportações entre 1982 e 1984 foi uma fonte maior de melhora da conta de mercadorias do que a substituição de importações não-petróleo".

Infere-se dessa breve resenha do debate sobre o II PND que questões referentes à promoção ou não de um ajuste estrutural em resposta ao problema do balanço de pagamentos possuem uma conexão natural com a abordagem do crescimento econômico sob restrição externa. Embora essa conexão já tenha sido apontada na literatura específica, sua eventual análise sempre se deu de maneira indireta, posto que baseada em uma versão agregada da LT. Logo, a contribuição do presente artigo para a literatura sobre o II PND reside no uso da LTMS para uma investigação da conexão direta entre mudança estrutural, sob a forma de transformação da composição setorial da estrutura de comércio exterior, e intensidade da restrição externa. Para tanto, uma questão relevante a ser respondida é se a "estratégia de 1974" direcionou os investimentos para os setores que, de fato, aliviariam a intensidade daquela restrição, ou seja, se buscou aumentar a participação nas exportações e diminuir a participação das importações de setores com maior elasticidade-renda ${ }^{5}$. Como visto anteriormente, Castro (1985), por meio de seu cálculo de ganho de divisas, sugere que sim.

\section{Dados, estimações e validade da Lei de Thirlwall Multissetorial: Brasil 1962- 2006}

\subsection{Fonte e classificação dos dados}

Os dados de comércio foram obtidos na United Nations Commodity Trade Statistics Database (Comtrade). Como os exercícios empíricos que se seguem são baseados em um modelo de crescimento de longo prazo e pretendem dialogar com a rica literatura sobre o II PND, foram utilizadas informações de comércio desagregadas relativas ao período de análise o mais extenso possível. Assim, os dados foram inicialmente obtidos segundo a Classificação Uniforme de Comércio Internacional (Cuci) Revisão 1 a 3 dígitos, para a qual há informações sobre exportações e importações de produtos brasileiros disponíveis de 1962 a 2006.

Para captar, de maneira mais apropriada, os aspectos relativos à mudança estrutural na economia brasileira, optou-se por elaborar uma Nova Classificação com o intuito de organizar os dados (Quadros 1 e 2 do Anexo 1). Na Nova

(5) Os trabalhos de Carbinato (2009) e, com antecedência e maior aprofundamento econométrico, de Gouvêa e Lima (2010) foram os primeiros a utilizar a LTMS em uma análise empírica da relação entre mudança estrutural e crescimento sob restrição externa no Brasil. Em ambos os casos, a fonte de informação e o período analisado são semelhantes aos do presente estudo. Porém, as classificações adotadas nesses trabalhos anteriores (intensidade tecnológica no segundo e CUCI 1 dígito no primeiro), assim como a inexistência de uma proxy para o efeito preço nas estimações do primeiro, são limitações reparadas no presente estudo. Além disso, nenhum desses estudos empíricos anteriores analisa direta e detalhadamente o II PND. 
Classificação, os dados de produtos da Cuci foram organizados por atividades econômicas. Esse processo foi desenvolvido em duas etapas. Primeiro, foi elaborada uma tabela de correspondência para os dados Cuci Revisão 1 a 3 dígitos para as divisões da Classificação Nacional de Atividades Econômicas (CNAE) 1.0. Para auxiliar o processo, foi utilizado o tradutor oficial da Nomenclatura Comum do Mercosul (NCM) para CNAE1.0, disponível no site do IBGE. A classificação NCM foi adotada por Brasil, Argentina, Paraguai e Uruguai em janeiro de 1995 e tem por base o Sistema Harmonizado de Designação e de Codificação de Mercadorias, que é o método internacional de classificação de produtos mais atualizado. A escolha desse tradutor em particular como apoio deve-se ao fato de a classificação Cuci também ser uma classificação de produtos/mercadorias. A segunda etapa consistiu em definir como seriam agregados os grupos finais. Esse processo foi baseado na revisão da literatura sobre história econômica do período e na necessidade, de uma perspectiva econométrica, de viabilizar as estimações. $\mathrm{O}$ Anexo 1 apresenta a agregação final dos setores da Nova Classificação por códigos Cuci Rev.1 e um resumo com exemplos de produtos pertencentes a cada um deles $^{6}$. As outras variáveis utilizadas nas estimações são o produto interno bruto brasileiro, o produto interno bruto mundial e a taxa de câmbio real brasileira. As séries de produto foram obtidas no World Development Indicators (Banco Mundial) e estão em dólares constantes de 2000. Já a série de taxa de câmbio real foi construída como sendo o produto entre a taxa de câmbio oficial média (moeda local/dólares) e a razão entre o índice de preços ao atacado (IPA) dos Estados Unidos e o IPA brasileiro, sendo 2000 o ano base dos índices de preços. Nesse caso, a fonte de informações é o International Financial Statistics (FMI). Por sua vez, as séries de comércio, que são divulgadas pelo Comtrade em dólares correntes, foram deflacionadas pelo IPA americano.

\subsection{Estimação das funções de demanda}

A primeira etapa do exercício empírico consiste na estimação, utilizando-se de metodologias de séries temporais, das funções de demanda por importações e exportações com o intuito de se obter estimativas para as elasticidades-renda agregadas e setoriais, que são os parâmetros que determinam a intensidade da restrição externa na LT e LTMS, respectivamente. Portanto, foram estimadas as seguintes equações para a economia brasileira:

$$
\begin{gathered}
\ln M_{i t}=\pi_{i} \ln y_{t}+\psi_{i} \ln \left(p f_{t}+E_{t}-p d_{t}\right) \text { MERGEFORMAT } \\
\ln X_{i t}=\varepsilon_{i} \ln z_{t}+\eta_{i} \ln \left(p f_{t}+E_{t}-p d_{t}\right) \text { MERGEFORMAT, }
\end{gathered}
$$

(6) Os tradutores estão disponíveis na página da Comissão Nacional de Classificação (http://www.ibge.gov.br/concla). O tradutor CNAE1.0 x CUCI Rev. 1 pode ser obtido com os autores através de solicitação. 
onde t é o índice de tempo, $i=1,2, \ldots, 18$ representa os setores e $i=0$ representa as funções agregadas. $\pi_{i}, \psi_{i}, \varepsilon_{i}$ e $\eta_{i}$ são, respectivamente, as elasticidades-renda e preço das importações e exportações setoriais. Por sua vez, $z_{t}$ e $y_{t}$ denotam o produto interno mundial e brasileiro, respectivamente. $p f_{t}+E_{t}-p d_{t}$ é a taxa de câmbio real que será utilizada na estimação setorial como proxy para a taxa de câmbio real setorial.

A aplicação dos testes de raiz unitária ADF e KPSS das séries envolvidas nas equações indicou que as mesmas são não estacionárias. Como todas as variáveis são integradas de ordem 1, utilizou-se a metodologia de Johansen (1995) para testar se as séries são cointegradas. Quando não foi possível rejeitar a hipótese nula de existência de pelo menos um vetor de cointegração, as equações foram estimadas usando-se a metodologia de Johansen. O número de defasagens utilizadas para a realização dos testes de cointegração foi escolhido empregando-se os critérios de informação para a definição das defasagens dos modelos VAR auxiliares ${ }^{7}$.

Tabela 2

Resultado das estimações das funções de demanda por exportações e importações para a economia brasileira: 1962-2006

\begin{tabular}{lcc}
\hline Variáveis & Exportações & Importações \\
\hline $\log$ Câmbio Real & $0,902^{* * *}$ & $-2,542^{* * *}$ \\
$\log$ Produto Mundial $/ \log$ Produto & $2,021^{* * *}$ & $1,613^{* * *}$ \\
\hline$* * * p<0,01, * * p<0,05, * \mathrm{p}<0,1$ & & \\
Fonte: Elaboração própria. & &
\end{tabular}

A Tabela 2, acima, apresenta os resultados das estimações das funções de demanda por exportações e importações da economia brasileira no período 1962 2006. As elasticidades obtidas possuem o sinal esperado, ou seja, positivo para as elasticidades-renda e para a elasticidade-preço das exportações e negativo para a elasticidade-preço das importações. Observa-se que a elasticidade-renda das exportações é superior à elasticidade-renda das importações em aproximadamente 0,40. Além disso, os resultados sugerem que a intensidade de reação das importações a variações no câmbio real é maior que a das exportações.

Na Tabela 3, são apresentadas as estimativas obtidas para as elasticidadesrenda e preço das importações e exportações dos diferentes setores. Como se observa, para todos os setores, as elasticidades-renda foram significantes a $1 \%$, exceto a elasticidade-renda das exportações do setor Vestuário, Couros e Calçados,

(7) Os resultados dos testes de raiz unitária, testes de cointegração por Johansen (máximo autovalor e traço) e demais informações sobre as estimações, como, por exemplo, as análises de correlação e normalidade dos resíduos, podem ser obtidos com os autores através de solicitação. 
significante a 5\%. Para as elasticidades-preço, os resultados em termos de significância possuem maior variabilidade. No caso das exportações, somente para os setores metalúrgicos, a variável câmbio real se mostrou significante a pelo menos 5\%. Em alguns casos - Borracha e Plástico; Papel e Celulose; Têxtil; Produtos Minerais Não Metálicos; Extração de Outros Minerais; Fertilizantes; Produtos Químicos e Produtos Diversos - a elasticidade-preço das exportações apresentou sinal não esperado, porém não significante em todos eles. Para as importações, somente nos setores de Vestuário, Couros e Calçados; Petróleo e Combustíveis; Extração de Minerais Não Ferrosos e Fertilizantes, as elasticidadespreço foram não significantes. Em todos os outros casos, exceto Extração de Outros Minerais, a elasticidade-preço das importações apresentou sinal esperado e significante a pelo menos $5 \%$ de significância. A elasticidade-preço das importações do setor Extração de Outros Minerais foi a única a apresentar sinal contrário ao esperado e significante. Uma possível explicação para essa diferença de resultados do efeito do câmbio real sobre as exportações e importações setoriais pode estar relacionada com o fato de que taxas de câmbio múltiplas foram utilizadas na economia brasileira como importante instrumento para a promoção de substituição de importações até meados da década de 1980.

Tabela 3

Resumo dos resultados das estimações das funções de demanda por exportações e importações setoriais: Brasil 1962-2006

\begin{tabular}{|c|c|c|c|c|}
\hline \multirow[b]{2}{*}{ Setores } & \multicolumn{2}{|c|}{ Exportações } & \multicolumn{2}{|c|}{ Importações } \\
\hline & $\begin{array}{c}\text { Elasticidade- } \\
\text { preço }\end{array}$ & $\begin{array}{c}\text { Elasticidade- } \\
\text { renda }\end{array}$ & $\begin{array}{c}\text { Elasticidade- } \\
\text { preço }\end{array}$ & $\begin{array}{c}\text { Elasticidade- } \\
\text { renda }\end{array}$ \\
\hline Alimentos & 0,988 & $0,792 * * *$ & $-0,828 * *$ & $0,641 * * *$ \\
\hline Madeira e Mobiliário & 1,292 & $4,587 * * *$ & $-2,322 * * *$ & $2,173 * * *$ \\
\hline Borracha e Plástico & $-1,027$ & $0,811^{* * *}$ & $-2,145^{* * *}$ & $1,836^{* * *}$ \\
\hline Papel e Celulose & $-0,157$ & $2,542 * * *$ & $-2,743 * * *$ & $1,076^{* * *}$ \\
\hline Têxtil & $-1,888$ & $0,575 * * *$ & $-3,724 * * *$ & $1,846^{* * *}$ \\
\hline Vestuário, Couros e Calçados & 0,320 & $8,298 * *$ & $-1,794$ & $4,176^{* * *}$ \\
\hline Produtos Minerais Não Metálicos & $-0,968$ & $1,749 * * *$ & $-2,967 * * *$ & $0,733 * * *$ \\
\hline Petróleo e Combustíveis & 2,417 & $0,825 * * *$ & $-0,256$ & $1,892 * * *$ \\
\hline Extração de Minerais Não Ferrosos & 1,123 & $0,671 * * *$ & $-0,891$ & $0,783 * * *$ \\
\hline Extração de Outros Minerais & $-0,217$ & $0,760 * * *$ & $2,178 * *$ & $0,690 * * *$ \\
\hline Metalurgia de Minerais Não Ferrosos & $7,576 * * *$ & $4,018 * * *$ & $-2,624 * * *$ & $0,945 * * *$ \\
\hline Metalurgia de Outros Minerais & $1,615 * *$ & $2,511 * * *$ & $-2,539 * * *$ & $0,880 * * *$ \\
\hline Fertilizantes & $-0,583$ & $3,620 * * *$ & $-1,200$ & $1,773 * * *$ \\
\hline Produtos Químicos & $-0,821$ & $1,252 * * *$ & $-2,001 * * *$ & $1,434 * * *$ \\
\hline Máquinas e Equipamentos & 0,179 & $6,140 * * *$ & $-2,683 * * *$ & $1,206 * * *$ \\
\hline Material Elétrico e de Comunicação & 0,419 & $2,426 * * *$ & $-3,001 * * *$ & $1,717 * * *$ \\
\hline Equipamento de Transporte & 0,160 & $2,186 * * *$ & $-3,149 * * *$ & $1,596^{* * *}$ \\
\hline$\underline{\text { Produtos Diversos }}$ & $-0,372$ & $1,597 * * *$ & $-2,441 * * *$ & $1,288 * * *$ \\
\hline
\end{tabular}

$* * * \mathrm{p}<0,01, * * \mathrm{p}<0,05, * \mathrm{p}<0,1$

Fonte: Elaboração própria. 


\subsection{Testes de validade da Lei de Thirlwall e da Lei de Thirlwall Multissetorial para a economia brasileira: 1962-2006}

Esta seção utiliza a metodologia de McCombie (1989) para verificar se o crescimento da economia brasileira no período 1962-2006 foi condicionado pela restrição de divisas. Por essa metodologia, primeiramente, define-se a elasticidaderenda das importações hipotética como aquela que gera igualdade entre a taxa de crescimento observada e a taxa de crescimento compatível com o equilíbrio externo. Em seguida, testa-se a hipótese nula de que a elasticidade-renda das importações estimada é igual à elasticidade-renda hipotética. A não rejeição da hipótese nula implica que não se pode rejeitar a hipótese de que o crescimento do país foi restrito pelo balanço de pagamentos. Como destacam Carvalho e Lima (2009, p. 44), "uma maneira análoga de aplicar essa metodologia consiste em comparar a taxa de crescimento prevista pelo modelo e a taxa de crescimento real". Desse modo, primeiro aplica-se, às fórmulas abaixo, as estimativas de elasticidades-renda obtidas na seção anterior e calculam-se as taxas de crescimento compatível com o equilíbrio externo dadas pela LT e LTMS. Em seguida, as taxas de crescimento previstas pelos modelos e a taxa de crescimento efetiva são comparadas, com a proximidade entre as duas taxas indicando a validade do modelo. Os resultados foram reportados na Tabela 4, que apresenta as médias das taxas de crescimento efetivas e as definidas pela LT e LTMS.

Modelo 1: Lei de Thirlwall Original (LT) - a taxa de crescimento da renda per capita é dada pela razão entre a elasticidade-renda das exportações e a elasticidade-renda das importações multiplicada pela taxa de crescimento per capita do produto mundial (Thirlwall, 1979).

Modelo 2: Lei de Thirlwall Multissetorial (LTMS) - a taxa de crescimento da renda per capita é dada pela multiplicação da taxa de crescimento da renda per capita mundial pela razão entre a elasticidade-renda ponderada das exportações e a elasticidade-renda ponderada das importações, sendo os pesos dados pelas participações de cada setor na pauta correspondente (Araújo; Lima, 2007) ${ }^{8}$.

(8) A apresentação dos modelos em que se derivam esses resultados foi omitida por questões de espaço. Entretanto, como bem observado pelo parecerista, vale esclarecer que grande parte dos trabalhos avalia a Lei de Thirlwall em termos de produto e não produto per capita. Porém, como, nesses modelos, a taxa média de crescimento populacional é uma variável exógena observada, a realização do teste de validade do modelo utilizando o nível do produto ou o produto per capita é equivalente. Para maiores detalhes sobre a derivação formal dos modelos, ver Thirlwall (1979) e Araujo e Lima (2007). 
Tabela 4

Taxas de crescimento per capita: Lei de Thirlwall, Lei de Thirlwall Multissetorial e efetiva

\begin{tabular}{l|c|c|c|}
\hline & LT & LTMS & Efetiva \\
\hline Crescimento Médio 1962-2006 (\%) & 2,39 & 2,29 & 2,22 \\
\hline Estatística t-Student & $-0,045$ & $-0,056$ & \\
\hline
\end{tabular}

Fonte: Elaboração própria.

Segundo o teste t-student reportado na tabela, não se pode rejeitar a hipótese de que as taxas de crescimento compatível com o equilíbrio externo são distintas da taxa efetiva do período. Conforme se observa, tanto a LT quanto a LTMS superestimam um pouco a taxa de crescimento efetivo. Entretanto, é interessante notar que o erro de previsão dos modelos é pequeno, ou seja, de $0,17 \%$ no caso da LT e de $0,07 \%$ no caso da LTMS.

Uma vez implementada a metodologia de McCombie (1989), procura-se, a seguir, usar a estratégia do teste de regressão - também amplamente utilizada na literatura empírica de modelos de crescimento sob restrição externa -, que consiste em regredir a taxa de crescimento efetiva contra a taxa de crescimento dada pelo modelo. Em seguida, verifica-se se é possível ou não rejeitar a hipótese nula de que a declividade e o intercepto da reta de regressão são iguais a 1 e 0 , respectivamente. Os resultados apresentados na

Tabela 5, e representados também no Gráfico 1, sugerem a validade do modelo, uma vez que, pelo teste $\mathrm{F}$ de restrições conjuntas, não é possível rejeitar a hipótese nula.

Tabela 5

Teste da regressão de validade da Lei de Thirlwall Multissetorial: Brasil 1962-2006

\begin{tabular}{|c|c|c|}
\hline Variáveis & Crescimento PIB per capita & Crescimento PIB per capita \\
\hline \multirow[t]{2}{*}{ LT } & $0,871 * *$ & \\
\hline & $(0,372)$ & \\
\hline \multirow[t]{2}{*}{ LTMS } & & $0,830^{*}$ \\
\hline & & $(0,434)$ \\
\hline \multirow[t]{2}{*}{ Constante } & 0,132 & 0,442 \\
\hline & $(1,085)$ & $(1,151)$ \\
\hline Número de Observações & 45 & 45 \\
\hline R2 Ajustado & 0,127 & 0,069 \\
\hline
\end{tabular}

Erros-padrão robustos entre parênteses / *** $\mathrm{p}<0,01, * * \mathrm{p}<0,05, * \mathrm{p}<0,1 /+\mathrm{p}$-valor estatística $\mathrm{F}(2,43)$ Fonte: Elaboração própria. 
Gráfico 1

Taxa de crescimento do PIB per capita, taxas de crescimento dadas pela LT e LTMS e testes da regressão para economia brasileira - médias 1962-2006

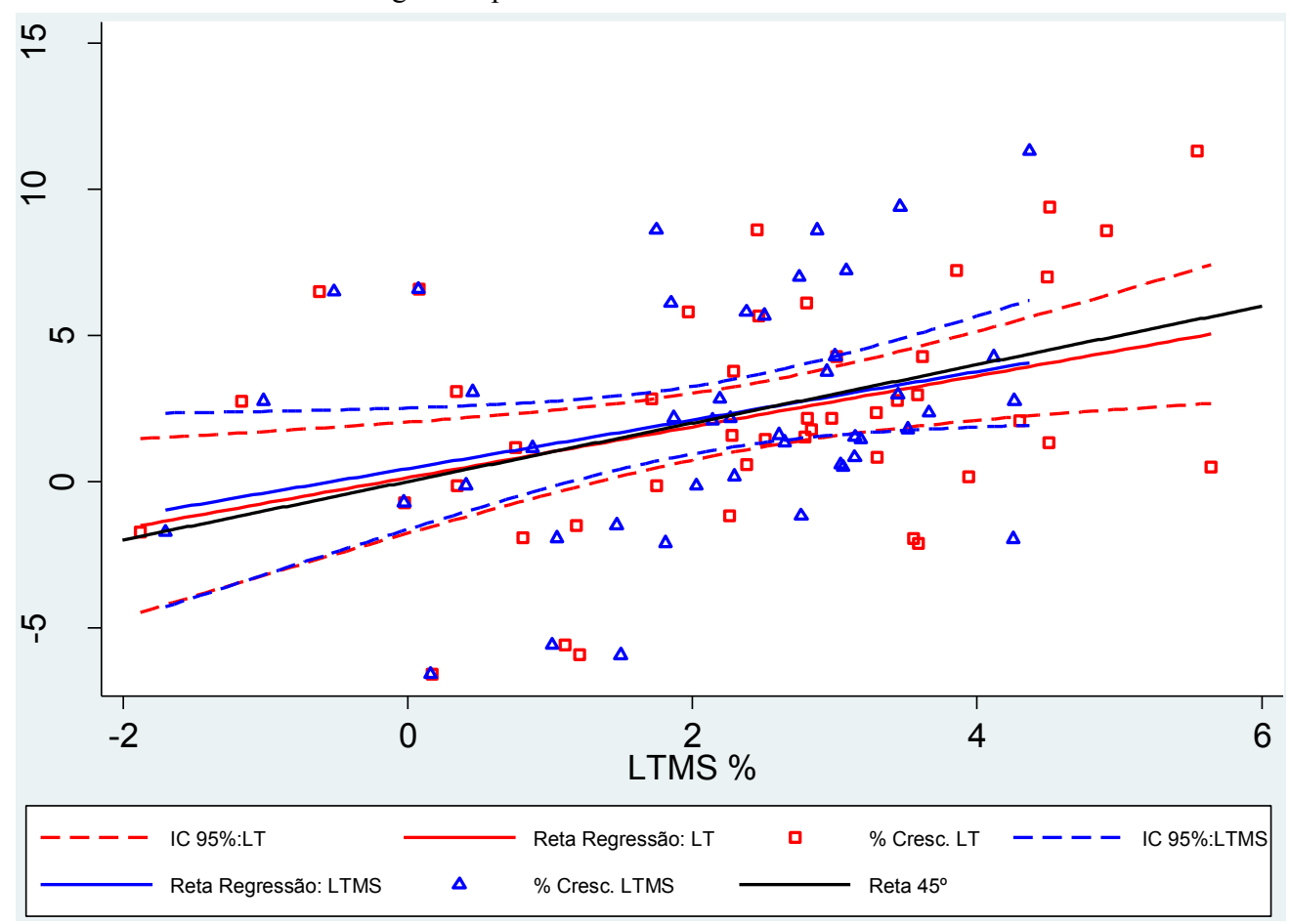

Logo, pode-se afirmar, a partir dos resultados anteriores, que o crescimento da economia brasileira no período 1962-2006 foi restrito pelo balanço de pagamentos, uma vez que não foi possível rejeitar a validade tanto da LT quanto da LTMS. Conforme revela a Tabela 4, há uma grande proximidade entre os valores previstos pela LT e pela LTMS para o crescimento médio do período, o que poderia levar ao questionamento de qual seria, então, a vantagem de se usar a versão setorial, já que parece inexistir ganho quantitativo expressivo em termos de poder preditivo do modelo com desagregação. Dois argumentos podem ser usados para responder a tal questionamento.

Primeiro, mesmo que não haja melhora expressiva na previsão do crescimento em um longo período de tempo, a versão setorial possibilita a realização de uma melhor conexão entre a coevolução da restrição externa e da mudança estrutural, compreendida, nesse caso, como o efeito composição da estrutura da balança comercial. Sendo assim, no modelo setorial, é possível captar, ao longo da trajetória de crescimento, os efeitos das alterações de curto e médio prazo na estrutura de comércio, como será feito em seguida. Segundo, de uma perspectiva positiva, a avaliação de ações de política econômica voltadas para o 
alívio da restrição externa impõe a necessidade de se avaliar questões setoriais, já que a intensidade da restrição depende não apenas das elasticidades setoriais, mas, inclusive, dos pesos de cada setor na composição das exportações e importações, tal como demonstrado por Araújo e Lima (2007).

Como os resultados discutidos acima sugerem a validade do modelo setorial para o Brasil, espera-se, na próxima seção, exemplificar os pontos destacados no parágrafo anterior ao se analisar a experiência de mudança estrutural brasileira no período 1962-2006.

\section{Mudança estrutural na economia brasileira: efeito composição e evolução das elasticidades como novas evidências sobre o II PND}

Como os resultados da seção anterior sugerem a validade do modelo multissetorial para o Brasil, avalia-se agora a utilização da LTMS para analisar a evolução das elasticidades -renda das exportações e importações ponderadas e, logo, da intensidade da restrição externa. Essa análise tem sido feita na literatura empírica sobre a LT por meio do uso da técnica de rolling regressions, que consiste em se realizar estimações por MQO em intervalos sequenciais (Cimoli et al., 2010; Pacheco-López; Thirlwall, 2006). O método aqui utilizado para se fazer essa análise, tal como em Gouvêa e Lima (2010), consistiu em ponderar, ano a ano, as elasticidades-renda setoriais estimadas anteriormente pela participação do setor na pauta de importações e exportações. Desse modo, foi possível captar a mudança estrutural no sentido estrito de alterações da composição setorial de comércio do país ${ }^{9}$.

O Gráfico 2 apresenta as trajetórias dessas elasticidades, da razão entre elas, suas médias móveis de 5 anos e a média do período. A apresentação da média móvel tem como objetivo eliminar os efeitos de curtíssimo prazo sobre a estrutura de comércio, o que permite destacar a tendência de evolução dessas variáveis. Ao analisar as trajetórias das médias móveis, observa-se que o período 1962-2006 pode ser dividido em dois subperíodos. No primeiro (1962-1995), a razão entre a elasticidade-renda ponderada das exportações e a elasticidade-renda ponderada das importações se eleva, passando a ser superior a 1 a partir de 1973. Dois componentes explicam esse comportamento. Primeiro, o rápido crescimento da elasticidade-renda das exportações, indicando que o país foi capaz de alterar sua estrutura de exportação para setores de maior elasticidade-renda. Segundo, a elasti-

(9) Como observado pelo parecerista, uma alternativa para incorporar alterações nas elasticidades, não só pela via do efeito composição, mas também por quebras estruturais nos parâmetros estimados, seria a realização de testes de quebra, como encontrado, por exemplo, em Bagnai (2010). Porém, vale destacar que o erro em não se considerar uma quebra estrutural quando ela existe tende a gerar resultados de rejeição da hipótese de cointegração, o que, como apresentado anteriormente, não acontece em nossos resultados. 
cidade-renda ponderada das importações diminui de 1985 a 1994, permanecendo praticamente constante até 2000, quando passa a apresentar ligeiro crescimento. No segundo período (1995-2006), há redução da razão de elasticidades ponderadas, causada principalmente pela queda da elasticidade-renda ponderada das exportações a partir de 1995. Essa redução está associada, portanto, a um processo de reversão da trajetória anterior de mudança da estrutura de exportações. É interessante observar, também, que a diferença entre as médias da elasticidaderenda ponderada das exportações e das importações para o período 1962-2006 foi de 0,44 , valor próximo ao encontrado anteriormente para as estimações das funções agregadas $(0,40)$.

\section{Gráfico 2}

Evolução da elasticidade-renda ponderada das exportações e importações e da razão de elasticidades ponderadas - Brasil 1962-2006

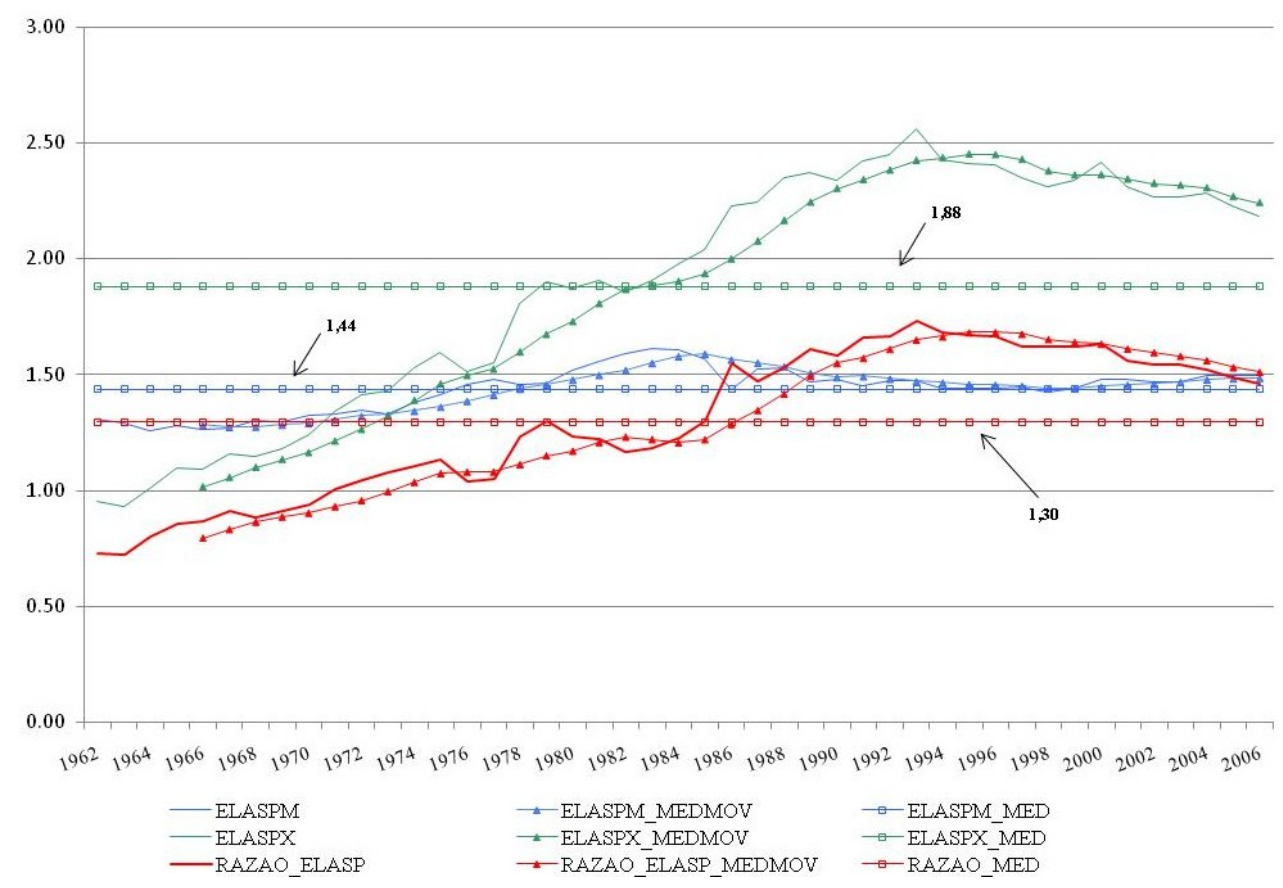

A partir da análise do Gráfico 2, algumas observações podem ser feitas em relação às interpretações do II PND, ainda que de maneira indireta, uma vez que não se observa diretamente o comportamento setorial. A elasticidade-renda ponderada das exportações apresenta uma trajetória ascendente desde o início do período, mas, nos primeiros anos da década de 1980, sua taxa de crescimento havia reduzido. Entretanto, a partir de 1984, acelera-se novamente o crescimento dessa variável, que alcança seu maior valor em 1995, quando começa a declinar. 
Também em 1984, a elasticidade-renda ponderada das importações atinge seu valor máximo, sendo que a partir desse momento entra em uma trajetória declinante até $1994^{10}$. Esses resultados parecem sugerir que estava correta a sugestão de Castro (1985) de que os investimentos do II PND ajudaram a promover um ajuste estrutural do balanço de pagamentos. A seguir, pretende-se aprofundar a conexão entre os resultados pioneiros obtidos anteriormente e alguns aspectos da literatura sobre o II PND, avaliando-se, para tanto, a contribuição dos setores para a realização do ajuste delineado pela trajetória das elasticidades. Os anos de 1974 e 1984 são utilizados como base de comparação.

A Tabela 6 apresenta a parcela e a contribuição de cada setor na elasticidade-renda ponderada das exportações para os anos 1974 e 1984. Nas duas últimas colunas, são apresentadas, respectivamente, a variação na parcela da elasticidade de cada setor e o quanto esta variação representa da diferença entre a elasticidade-renda ponderada das exportações em 1974 e 1984. Pelos resultados da última coluna, é possível agregar os setores em dois grupos: um, composto pelos setores que contribuíram negativamente para a alteração da elasticidade em questão e, outro, pelos setores que contribuíram positivamente. No primeiro grupo estão os setores de Alimentos; Madeira e Mobiliário; Têxtil; Produtos Diversos e os dois setores de extração de minerais. O segundo é composto pelos setores de Borracha e Plástico; Papel e Celulose; Produtos Minerais Não Metálicos; Petróleo e Combustíveis; Fertilizantes; Produtos Químicos; Máquinas e Equipamentos; Material Elétrico e de Comunicação; e Equipamento de Transporte. Como não há alteração das elasticidades setoriais, o presente exercício revela quais foram os setores que aumentaram ou diminuíram sua participação na pauta das exportações. Porém, o interessante é observar a contribuição de cada setor para o aumento de 0,45 na elasticidade-renda ponderada das exportações entre os anos 1974 e 1984, uma vez que, nesse caso, já se leva em consideração o efeito dado pelas diferenças nas elasticidades setoriais. O setor de maior contribuição negativa foi o de Alimentos, com aproximadamente 33\%, seguido por Madeira e Mobiliário, com $12 \%$. Com contribuição positiva, destacam-se os setores de Vestuário, Couros e Calçados (34,1\%), Equipamentos de Transporte $(11,9 \%)$ e os setores que participaram do II PND: Papel e Celulose (10,5\%), Petróleo e Combustíveis (9,9\%), Metalurgia de Não Ferrosos (13,9\%), Metalurgia de Outros Minerais (36,2\%), Produtos Químicos (8,9\%), Máquinas e Equipamentos (27,6\%).

(10) Resultados semelhantes foram encontrados por Giuberti (2009), que utilizou o Filtro de Kalman e MQO recursivo para estimar as funções de demanda por importação e exportação agregadas e obter, assim, a trajetória dos parâmetros dessas funções. 
Tabela 6

Participação setorial na elasticidade-renda ponderada das exportações - 1974 e 1984

\begin{tabular}{|c|c|c|c|c|c|c|}
\hline \multirow[b]{2}{*}{ Período } & \multicolumn{6}{|c|}{ Exportações } \\
\hline & \begin{tabular}{|c|} 
Elas. \\
Ponderada \\
1974 \\
\end{tabular} & $\begin{array}{c}\text { Contribuição } \\
\text { p/ Elas. } \\
\text { Pond. } 1974\end{array}$ & \begin{tabular}{|c|} 
Elas. \\
Ponderada \\
1984
\end{tabular} & $\begin{array}{c}\text { Contribuição } \\
\text { p/ Elas. } \\
\text { Pond. } 1984\end{array}$ & \begin{tabular}{|c|} 
Diferença \\
de Elas. \\
Ponderada
\end{tabular} & $\begin{array}{l}\text { Contribuição } \\
\text { p/ Diferença }\end{array}$ \\
\hline Alimentos & 0,460 & $30,1 \%$ & 0,308 & $15,6 \%$ & $-0,152$ & $-33,7 \%$ \\
\hline Madeira e Mobiliário & 0,115 & $7,5 \%$ & 0,061 & $3,1 \%$ & $-0,054$ & $-12,0 \%$ \\
\hline Borracha e Plástico & 0,002 & $0,1 \%$ & 0,008 & $0,4 \%$ & 0,007 & $1,4 \%$ \\
\hline Papel e Celulose & 0,023 & $1,5 \%$ & 0,070 & $3,5 \%$ & 0,047 & $10,5 \%$ \\
\hline Têxtil & 0,042 & $2,7 \%$ & 0,023 & $1,2 \%$ & $-0,019$ & $-4,2 \%$ \\
\hline $\begin{array}{l}\text { Vestuário, Couros e } \\
\text { Calçados }\end{array}$ & 0,311 & $20,4 \%$ & 0,464 & $23,5 \%$ & 0,153 & $34,1 \%$ \\
\hline $\begin{array}{l}\text { Produtos Minerais Não } \\
\text { Metálicos }\end{array}$ & 0,007 & $0,4 \%$ & 0,008 & $0,4 \%$ & 0,001 & $0,3 \%$ \\
\hline Petróleo e Combustíveis & 0,011 & $0,8 \%$ & 0,056 & $2,8 \%$ & 0,044 & $9,9 \%$ \\
\hline $\begin{array}{l}\text { Extração de Minerais } \\
\text { Não Ferrosos } \\
\end{array}$ & 0,006 & $0,4 \%$ & 0,005 & $0,2 \%$ & $-0,001$ & $-0,3 \%$ \\
\hline $\begin{array}{l}\text { Extração de Outros } \\
\text { Minerais }\end{array}$ & 0,056 & $3,7 \%$ & 0,048 & $2,4 \%$ & $-0,009$ & $-1,9 \%$ \\
\hline $\begin{array}{l}\text { Metalurgia de Minerais } \\
\text { Não Ferrosos }\end{array}$ & 0,015 & $1,0 \%$ & 0,078 & $3,9 \%$ & 0,062 & $13,9 \%$ \\
\hline $\begin{array}{l}\text { Metalurgia de Outros } \\
\text { Minerais }\end{array}$ & 0,059 & $3,9 \%$ & 0,222 & $11,2 \%$ & 0,163 & $36,2 \%$ \\
\hline Fertilizantes & 0,001 & $0,1 \%$ & 0,002 & $0,1 \%$ & 0,001 & $0,2 \%$ \\
\hline Produtos Químicos & 0,039 & $2,6 \%$ & 0,079 & $4,0 \%$ & 0,040 & $8,9 \%$ \\
\hline $\begin{array}{l}\text { Máquinas e } \\
\text { Equipamentos }\end{array}$ & 0,223 & $14,6 \%$ & 0,347 & $17,6 \%$ & 0,124 & $27,6 \%$ \\
\hline $\begin{array}{l}\text { Material Elétrico e de } \\
\text { Comunicação }\end{array}$ & 0,058 & $3,8 \%$ & 0,058 & $3,0 \%$ & 0,001 & $0,2 \%$ \\
\hline $\begin{array}{l}\text { Equipamento de } \\
\text { Transporte }\end{array}$ & 0,048 & $3,2 \%$ & 0,102 & $5,2 \%$ & 0,054 & $11,9 \%$ \\
\hline Produtos Diversos & 0,052 & $3,4 \%$ & 0,038 & $1,9 \%$ & $-0,013$ & $-2,9 \%$ \\
\hline Elasticidade Média & 1,526 & $100 \%$ & 1,976 & $100 \%$ & 0,450 & $100 \%$ \\
\hline
\end{tabular}

Fonte: Elaboração própria.

A Tabela 7, por sua vez, apresenta as mesmas informações da tabela anterior para o caso das importações. Os setores com contribuição negativa para o aumento de 0,23 na elasticidade-renda ponderada das importações entre 1974 e 1984 foram aqueles que, da perspectiva do efeito composição, promoveram a substituição de importações no período. Nesse grupo, destacam-se os setores de Metalurgia de Outros Minerais (45\%), Máquinas e Equipamentos (41,7\%), Produtos Químicos (18,5\%), Fertilizantes (18,5\%) e Metalurgia de Minerais Não Ferrosos (11\%). Fazem parte, ainda desse grupo, os setores de Produtos Diversos 
(9\%), Têxtil (7,2\%), Papel e Celulose (6,2\%), Material Elétrico e de Comunicação (4,2\%), Produtos Minerais Não Metálicos (1,3\%) e Equipamento de Transporte $(0,6 \%)$. A contribuição dos demais setores foi no sentido de aumentar a elasticidade-renda ponderada das importações. Destaca-se, nesse grupo, o setor de Petróleo e Combustíveis, que, como reflexo dos choques do petróleo, contribuiu com aproximadamente $240 \%$ para a elevação dessa elasticidade. Os demais setores que não contribuíram para o alívio da restrição externa foram: Vestuário, Couros e Calçados (13,4\%), Alimentos (4,6\%), Extração de Outros Minerais (1,7\%), Borracha e Plástico (1,6\%), Madeira e Mobiliário (0,6\%) e Extração de Minerais Não Ferrosos $(0,4 \%)$.

Tabela 7

Participação setorial na elasticidade-renda ponderada das importações - 1974 e 1984

\begin{tabular}{|c|c|c|c|c|c|c|}
\hline \multirow[b]{2}{*}{ Período } & \multicolumn{6}{|c|}{ Importações } \\
\hline & \begin{tabular}{|c|} 
Elas. \\
Ponderada \\
1974 \\
\end{tabular} & $\begin{array}{l}\text { Contribuição } \\
\text { p/ Elas. } \\
\text { Pond. } 1974\end{array}$ & \begin{tabular}{|c|} 
Elas. \\
Ponderada \\
1984 \\
\end{tabular} & \begin{tabular}{|c|} 
Contribuição \\
p/ Elas. \\
Pond. 1984
\end{tabular} & \begin{tabular}{|c|} 
Diferença \\
de Elas. \\
Ponderada
\end{tabular} & $\begin{array}{l}\text { Contribuição } \\
\text { p/ Diferença }\end{array}$ \\
\hline Alimentos & 0,05 & $3,6 \%$ & 0,06 & $3,8 \%$ & 0,01 & $4,6 \%$ \\
\hline Madeira e Mobiliário & 0,00 & $0,2 \%$ & 0,00 & $0,3 \%$ & 0,00 & $0,6 \%$ \\
\hline Borracha e Plástico & 0,02 & $1,4 \%$ & 0,02 & $1,4 \%$ & 0,00 & $1,6 \%$ \\
\hline Papel e Celulose & 0,02 & $1,7 \%$ & 0,01 & $0,6 \%$ & $-0,01$ & $-6,2 \%$ \\
\hline $\begin{array}{l}\text { Têxtil } \\
\text { Vestuário, Couros e }\end{array}$ & 0,03 & $2,0 \%$ & 0,01 & $0,7 \%$ & $-0,02$ & $-7,2 \%$ \\
\hline $\begin{array}{l}\text { Calçados } \\
\text { Produtos Minerais Não }\end{array}$ & 0,00 & $0,3 \%$ & 0,04 & $2,2 \%$ & 0,03 & $13,4 \%$ \\
\hline Metálicos & 0,00 & $0,3 \%$ & 0,00 & $0,1 \%$ & 0,00 & $-1,3 \%$ \\
\hline $\begin{array}{l}\text { Petróleo e Combustíveis } \\
\text { Extração de Minerais }\end{array}$ & 0,45 & $32,7 \%$ & 1,00 & $62,1 \%$ & 0,55 & $238,4 \%$ \\
\hline $\begin{array}{l}\text { Não Ferrosos } \\
\text { Extração de Outros }\end{array}$ & 0,00 & $0,3 \%$ & 0,00 & $0,3 \%$ & 0,00 & $0,4 \%$ \\
\hline $\begin{array}{l}\text { Minerais } \\
\text { Metalurgia de Minerais }\end{array}$ & 0,00 & $0,3 \%$ & 0,01 & $0,5 \%$ & 0,00 & $1,7 \%$ \\
\hline $\begin{array}{l}\text { Não Ferrosos } \\
\text { Metalurgia de Outros }\end{array}$ & 0,04 & $3,0 \%$ & 0,02 & $1,0 \%$ & $-0,03$ & $-11,0 \%$ \\
\hline Minerais & 0,12 & $8,4 \%$ & 0,01 & $0,7 \%$ & $-0,10$ & $-45,0 \%$ \\
\hline Fertilizantes & 0,07 & $5,2 \%$ & 0,03 & $2,2 \%$ & $-0,04$ & $-15,8 \%$ \\
\hline $\begin{array}{l}\text { Produtos Químicos } \\
\text { Máquinas e }\end{array}$ & 0,17 & $12,6 \%$ & 0,13 & $8,2 \%$ & $-0,04$ & $-18,5 \%$ \\
\hline $\begin{array}{l}\text { Equipamentos } \\
\text { Material Elétrico e de }\end{array}$ & 0,18 & $13,0 \%$ & 0,08 & $5,2 \%$ & $-0,10$ & $-41,7 \%$ \\
\hline $\begin{array}{l}\text { Comunicação } \\
\text { Equipamento de }\end{array}$ & 0,10 & $7,4 \%$ & 0,09 & $5,7 \%$ & $-0,01$ & $-4,2 \%$ \\
\hline Transporte & 0,06 & $4,1 \%$ & 0,05 & $3,4 \%$ & 0,00 & $-0,6 \%$ \\
\hline Produtos Diversos & 0,05 & $3,5 \%$ & 0,03 & $1,7 \%$ & $-0,02$ & $-9,0 \%$ \\
\hline Elasticidade Média & 1,38 & $100 \%$ & 1,61 & $100 \%$ & 0,23 & $100 \%$ \\
\hline
\end{tabular}

Fonte: Elaboração própria. 
O Quadro 1 sintetiza os resultados em termos da contribuição dos setores para a promoção de exportações e substituição de importações. Em negrito, foram ressaltados os setores que receberam os grandes projetos de investimentos do II PND. Como se pode observar, a "safra de 1974" contribuiu para a realização do ajuste estrutural do balanço de pagamentos. Os resultados sugerem que todos os setores focalizados pelo II PND, em maior ou menor grau, contribuíram, por meio da alteração das elasticidades-renda do comércio exterior, para um ajuste estrutural tanto no que se refere às importações quanto às exportações. A única exceção, como era de se esperar, foi o setor de Petróleo e Combustíveis, o maior responsável pelo aumento da elasticidade-renda ponderada das importações.

Quadro 1

Contribuição dos setores para promoção de exportações e substituição de importações

\begin{tabular}{|c|c|c|c|}
\hline & Promoção de Exportações & Substituição de Importações \\
\hline \multirow[t]{2}{*}{ 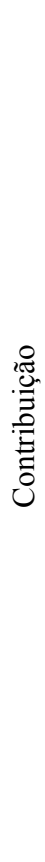 } & Positiva & $\begin{array}{l}\text { Borracha e Plástico } \\
\text { Papel e Celulose } \\
\text { Vestuário, Couros e Calçados } \\
\text { Produtos Minerais Não Metálicos } \\
\text { Petróleo e Combustíveis } \\
\text { Metalurgia de Minerais Não Ferrosos } \\
\text { Metalurgia de Outros Minerais } \\
\text { Fertilizantes } \\
\text { Produtos Químicos } \\
\text { Máquinas e Equipamentos } \\
\text { Material Elétrico e de Comunicação } \\
\text { Equipamento de Transporte }\end{array}$ & $\begin{array}{l}\text { Papel e Celulose } \\
\text { Têxtil } \\
\text { Produtos Minerais Não Metálicos } \\
\text { Metalurgia de Minerais Não Ferrosos } \\
\text { Metalurgia de Outros Minerais } \\
\text { Fertilizantes } \\
\text { Produtos Químicos } \\
\text { Máquinas e Equipamentos } \\
\text { Material Elétrico e de Comunicação } \\
\text { Equipamento de Transporte } \\
\text { Produtos Diversos }\end{array}$ \\
\hline & Negativa & $\begin{array}{l}\text { Alimentos } \\
\text { Madeira e Mobiliário } \\
\text { Têxtil } \\
\text { Extração de Minerais Não Ferrosos } \\
\text { Extração de Outros Minerais } \\
\text { Produtos Diversos }\end{array}$ & $\begin{array}{l}\text { Alimentos } \\
\text { Madeira e Mobiliário } \\
\text { Borracha e Plástico } \\
\text { Vestuário, Couros e Calçados } \\
\text { Petróleo e Combustíveis } \\
\text { Extração de Minerais Não Ferrosos } \\
\text { Extração de Outros Minerais }\end{array}$ \\
\hline
\end{tabular}

Logo, os resultados aqui reportados sugerem que a interpretação de Castro (1985) sobre o ajustamento externo promovido pelo II PND se sustenta também quando analisada, com o devido rigor econométrico, sob a métrica das elasticidades-renda do comércio exterior. É necessário ressaltar, porém, que a qualificação de Fishlow (1986) de que o ajuste teria ocorrido mais pela contribuição das exportações do que das importações também recebe suporte desses mesmos resultados. Isso porque, ainda que, dos setores contemplados pelo II PND, apenas o setor de Petróleo e Combustíveis não tenha contribuído para substituição de importações 
(possivelmente devido a seu peso distorcido dado pela grande alteração nos preços relativos), o Gráfico 2 revela claramente que a queda na razão de elasticidades no período é dada pelo aumento da elasticidade-renda das exportações. Claro está, portanto, que os setores que receberam os investimentos do II PND contribuíram para o ajuste externo tanto pela via da promoção de exportações como da substituição de importações.

\section{Considerações finais}

Este artigo analisou a experiência brasileira de crescimento econômico no período 1962-2006, utilizando modelos de crescimento sob restrição externa, especialmente uma versão multissetorial da Lei de Thirlwall. Por meio desta, investigamos implicações de uma mudançaestrutural na forma de alteração na composição da pauta de comércio exterior.

Inicialmente, testou-se a validade das versões original e multissetorial da Lei de Thirlwall para a economia brasileira com base em duas metodologias distintas. Os resultados revelaram que a taxa de crescimento per capita da economia brasileira no período 1962-2006 não diferiu, estatisticamente, das previstas por aquelas versões da Lei de Thirlwall. Portanto, pode-se afirmar que a restrição externa foi a restrição relevante para o desempenho de crescimento brasileiro no período.

Em seguida, partindo das implicações da versão multissetorial, desenvolveu-se um método para analisar como o efeito composição afetou a evolução da elasticidade-renda ponderada das importações e exportações e, portanto, da intensidade da restrição externa ao crescimento brasileiro. Foram identificados dois períodos distintos. No período 1962-1995, o país modificou sua estrutura de comércio de maneira a possibilitar uma redução da intensidade da restrição, uma vez que há elevação da razão entre a elasticidade-renda das exportações e a elasticidade-renda das importações. Os fatores que contribuíram para esse movimento foram uma elevação da elasticidade-renda ponderada das exportações durante o período e a reversão do crescimento da elasticidade-renda ponderada das importações de 1985 a 1994. Os anos 1994-1995, por sua vez, marcam o início do segundo período, no qual há redução da razão de elasticidadesrenda do comércio exterior. Essa redução é explicada principalmente pela queda da elasticidade-renda ponderada das exportações a partir de 1995, ainda que também se verifique uma ligeira elevação da elasticidade-renda ponderada das importações após 1999.

Por fim, como destacado na resenha de trabalhos representativos sobre o II PND, a análise empírica realizada neste artigo possui uma conexão direta com o debate sobre o plano. A razão é que o arcabouço utilizado permite avaliar a 
contribuição dos setores para o ajustamento externo, vale dizer, para a redução da intensidade da restrição externa. Assim, foi também reportada uma análise pioneira da contribuição de cada setor para os aumentos de 0,45 na elasticidade-renda ponderada das exportações e de 0,23 na elasticidade-renda ponderada das importações entre os anos de 1974 e de 1984. Embora o propósito não fosse testar interpretações particulares, mas apenas subsidiar uma melhor compreensão de certos aspectos do período, os resultados sugerem que a interpretação de Castro (1985), mesmo quando avaliada sob uma métrica diferente daquela utilizada pelo autor, possui fundamento empírico. Porém, é necessário ressaltar a qualificação de Fishlow (1986) de que a melhora verificada na balança comercial nos anos 19831984 decorreu mais do comportamento das exportações do que das importações. A razão é que, de fato, os setores contemplados no II PND contribuíram, no período, tanto para a promoção de exportações quanto para a substituição de importações. Ainda que a elasticidade-renda ponderada das exportações tenha aumentado, o mesmo ocorreu com a elasticidade-renda ponderada das importações - e, no caso desta última, não obstante a contribuição negativa de diversos setores, entre eles todos do II PND, com exceção do setor de petróleo e combustíveis.

\section{Referências bibliográficas}

AGUIRRE, B.; SADDI, F. Uma alternativa de interpretação do II PND. Revista de Economia Política, v. 17, n. 4, p. 78-98, 1997.

ARAUJO, R. A.; LIMA, G. T. A structural economic dynamics approach to balance-ofpayments-constrained growth. Cambridge Journal of Economics, v. 31, n. 5, p. 755-774, 2007.

BAGNAI, A. Structural changes, cointegration and the empirics of Thirlwall's Law. Applied Economics, v. 42, n. 10, p. 1315-1329, 2010.

BAIRAM, E. Levels of economic development and appropriate specification of the Harrod foreign-trade multiplier. Journal of Post Keynesian Economics, v. 19, n. 3, p. 337-344, 1997.

BALASSA, B. Incentive policies in Brazil. World Development, v. 7, p. 1023-1042, 1979.

BARBOSA-FILHO, Nelson. The balance-of-payments constraint: from balanced trade to sustainable debt. Banca Nazionale del Lavoro Quarterly Review, v. 54, n. 219, p. 381-400, 2001.

BÉRTOLA, L.; HIGACHI, H.; PORCILE, G. Balance-of-payments-constrained growth in Brazil: a test of Thirlwall's Law, 1890-1973. Journal of Post Keynesian Economics, v. 25, n. 1, p. 123-140, 2002.

BRASIL. II Plano Nacional de Desenvolvimento (1975-1979). Brasília, 1974. 
BRITO, G.; McCOMBIE, J. S. L. Thirlwall's Law and the long-term equilibrium growth rate: an application to Brazil. Journal of Post Keynesian Economics, v. 32, n. 1, p. 115-136, 2010 .

CARBINATO, D. Mudanças estruturais e crescimento econômico: uma análise sobre as relações entre padrão setorial e restrição externa. Monografia (Graduação em Economia)Departamento de Economia, FEA-USP, 2009. (1 ${ }^{\circ}$ Lugar no XIV Prêmio CORECON-SP de Excelência Acadêmica).

CARVALHO, Veridiana R. A restrição externa e a perda de dinamismo da economia brasileira: investigando as relações entre estrutura produtiva e crescimento econômico. Rio de Janeiro: BNDES, 2007.

; LIMA, G. T. Macrodinâmica do produto e da renda sob restrição externa: a experiência brasileira no período 1930-2004. Economia Aplicada, v. 12, n. 1, p. 55-77, 2008.

Estrutura produtiva, restrição externa e crescimento econômico: a experiência brasileira. Economia e Sociedade, Campinas, v. 18, n. 1 (35), p. 31-60, abr. 2009.

CARVALHO, Veridiana R.; LIMA, G. T. SANTOS, A. T. L. A. A restrição externa como fator limitante do crescimento econômico brasileiro: um teste empírico. Revista EconomiA, v. 9 , n. 2, p. 285-387, 2008.

CASTRO, A. B; Ajustamento x transformação. A economia brasileira de 1974 a 1984. In: CASTRO, A. B.; SOUZA, F. P. A economia brasileira em marcha forçada. São Paulo: Paz e Terra, 1985.

CIMOLI, M.; PORCILE, G.; ROVIRA, S. Structural change and the BOP-Constraint: why did Latin America fail to converge? Cambridge Journal of Economics, v. 34, n. 2, 2010.

DICKEY, D. A.; FULLER, W. A. Distribution of the estimators for autoregressive time series with a unit root. Journal of the American Statistical Association, v. 74, n. 366, 427$41,1979$.

DUTT, A. K. Income elasticities of imports, North-South trade and uneven development. In: DUTT, A. K.; ROS, J. (Org.). Development economics and structuralist macroeconomics: essays in honor of Lance Taylor. Cheltenham, UK; Northampton, MA: Edward Elgar, 2003. p. 307-335.

FISHLOW, A. A economia política do ajustamento brasileiro aos choques do petróleo: uma nota sobre o período 1974/84. Pesquisa e Planejamento Econômico, v. 16, n. 3, p. 507$550,1986$.

FONSECA, P. C. D.; MONTEIRO, S. M. O Estado e suas razões: o II PND. Revista de Economia Política, v. 28, n. 1, p. 28-46, 2008.

GIUBERTI, A. C. Instabilidade dos parâmetros das equações de importação e exportação na abordagem do crescimento sob restrição externa. São Paulo: Departamento de Economia da FEA-USP, 2009. Mimeo. 
GOUVÊA, R. R.; LIMA, G. T. Structural change, balance-of-payments constraint and growth: evidence from the Multi-Sector Thirlwall's Law. Journal of Post Keynesian Economics, v. 33, p. 171-206, 2010.

framework: a panel data investigation. Journal of Economic Studies, v. 40, n. 2, 2013.

JAYME JR., F. G. Growth under external constraints in Brazil: a post Keynesian approach. In: HOLT, R.; PRESSMAN, S. (Org.). Empirical Post Keynesian economics: looking at the real world. New York: M. E. Sharpe, 2007. p. 305-328.

JOHANSEN, S. Likelihood based inference in cointegrated vector auto-regressive models. Oxford: Oxford University Press, 1995.

LESSA, C. Estratégia de Desenvolvimento, 1974-1976: sonho e fracasso. Campinas: Unicamp. IE, 1978.

McCOMBIE, J. S. L. Thirlwall's Law and balance-of-payments-constrained growth: a comment on the debate. Applied Economics, v. 21, p. 9-20, 1989.

; ROBERTS, M. The role of balance of payments in economic growth. In: SETTERFIELD, Mark (Org.). The economics of demand-led growth: challenging the supply-side vision of the long run. Cheltenham, UK; Northampton, MA: Edward Elgar, 2002. p. 87-114.

; THIRLWALL, J. P. Economic growth and balance-of-payments-constraint revisited. In: ARESTIS, P.; PALMA, G.; SAWYER, M. (Ed.). Markets, unemployment and economic policy, v. II. London: Toutledge, 1997.

MORENO-BRID, J. C. On capital flows and the balance-of-payments-constrained growth model. Journal of Post Keynesian Economics, v. 21, n. 2, p. 283-298, 1998-99.

NARETTO, N. A estratégia econômica do governo Geisel em debate. Dissertação (Mestrado em Economia)-Programa de Pós-Graduação em Economia, Instituto de Economia da Universidade Estadual de Campinas, 1994.

PACHECO-LÓPEZ, P.; THIRLWALL, A. P. Trade liberalization, the income elasticity of imports and economic growth in Latin America. Journal of Post Keynesian Economics, v. 29, n. 1, p. 41-66, 2006.

PALLEY, T. I. Pitfalls in the theory of growth. In: SETTERFIELD, Mark (Org.). The economics of demand-led growth: challenging the supply-side vision of the long run. Cheltenham, UK; Northampton, MA: Edward Elgar, 2002. p. 115-125.

PASINETTI, L. Structural change and economic growth: a theoretical essay on the dynamics of the wealth of nations. Cambridge: Cambridge University Press, 1981.

Structural economic dynamics: a theory of the economic consequences of human learning. Cambridge: Cambridge University Press, 1993. 
SANTOS, F. G.; COLISTETE, R. P. Reavaliando o II PND: uma abordagem quantitativa. In: VIII CONGRESSO BRASILEIRO DE HISTÓRIA ECONÔMICA, 8, Campinas, SP, p. 1-32, 2009. Anais...

SETTERFIELD, Mark. 'History versus equilibrium' and the theory of economic growth. Cambridge Journal of Economics, v. 21, n. 3, p. 365-378, 1997.

SIMONSEN, M. A economia brasileira: perspectivas a curto e a médio prazo. Palestra proferida em São Paulo, em 31/01/1978. In: Palestras e Conferências 1974-1978. Brasília: Ministério da Fazenda, 1978. v. 7.

THIRLWALL, Antony. P. The balance of payments constraint as an explanation of international growth rate differences. Banca Nazionale Del Lavoro Quarterly Review, v. 128, p. 45-53, 1979.

Reflections on the concept of balance-of-payments-constrained growth. Journal of Post Keynesian Economics, v. 19, n. 3, p. 377-384, 1997.

- A natureza do crescimento econômico: um referencial alternativo para compreender o desempenho das nações. Brasília: IPEA, 2005

; HUSSAIN, M. N. The balance of payments constraint, capital flows and growth rate differences between developing countries. Oxford Economic Papers, v. 34, n. 3, p. 498-510, 1982.

VELLOSO, J. P. R. Brasil: a solução positiva. São Paulo: Abril-Tec, 1978.

A fantasia política: a nova alternativa de interpretação do II PND. Revista de Economia Política, v. 18, n. 2, p. 133-144, 1998. 


\section{Anexo 1}

Quadro 1

Descrição e agregação da Nova Classificação

\begin{tabular}{|c|c|}
\hline Setores & Cód. Cuci \\
\hline $\begin{array}{l}\text { Alimentos, brutos e processados, Animais } \\
\text { Vivos, Bebidas e Fumo }\end{array}$ & $\begin{array}{l}\mathrm{S} 1-001 ; \mathrm{S} 1011 ; \mathrm{S} 1-012 ; \mathrm{S} 1-013 ; \mathrm{S} 1-022 ; \mathrm{S} 1-023 ; \mathrm{S} 1-024 ; \mathrm{S} 1- \\
\text { 025; S1-031; S1-032; S1-041; S1-042; S1-043; S1-044; S1-045; } \\
\text { S1-046; S1-047; S1-048; S1-051; S1-052; S1-053; S1-054; S1- } \\
\text { 055; S1-061; S1-062; S1-071; S1-072; S1-073; S1-074; S1-075; } \\
\text { S1-081; S1-091; S1-099; S1-111; S1-112; S1-121; S1-122; S1- } \\
\text { 211; S1-212; S1-221; S1-241; S1-291; S1-292; S1-411; S1-421; } \\
\text { S1-422; S1-941 }\end{array}$ \\
\hline Madeira, Produtos em Madeira e Mobiliário & S1-242; S1-243; S1-244; S1-631; S1-632; S1-633; S1-821 \\
\hline Artigos de Borracha e Plástico & S1-231; S1-621; S1-629; S1-893 \\
\hline Papel e Celulose & S1-251; S1-641; S1-642 \\
\hline Têxtil & $\begin{array}{l}\text { S1-261; S1-262; S1-263; S1-264; S1-265; S1-266; S1-267; S1- } \\
651 ; \text { S1-652; S1-653; S1-654; S1-655; S1-656; S1-657 }\end{array}$ \\
\hline Vestuário, couros e calçados & S1-611; S1-612; S1-613; S1-831; S1-841; S1-842; S1-851 \\
\hline $\begin{array}{l}\text { Fabricação de Produtos de Minerais Não } \\
\text { Metálicos }\end{array}$ & S1-661; S1-662; S1-664; S1-665; S1-666 \\
\hline $\begin{array}{l}\text { Coque, Petróleo, Elaboração de Combustíveis e } \\
\text { Energia }\end{array}$ & S1-321; S1-331; S1-332; S1-341; S1-515; S1-688 \\
\hline Extração de Minerais metálicos Não Ferrosos & S1-283; S1-284; S1-285; S1-286 \\
\hline $\begin{array}{l}\text { Extração de Minerais, exceto metálicos Não } \\
\text { Ferrosos }\end{array}$ & S1-273; S1-274; S1-275; S1-276; S1-281; S1-282 \\
\hline Metalurgia básica de Não Ferrosos & $\begin{array}{l}\text { S1-681; S1-682; S1-683; S1-684; S1-685; S1-686; S1-687; S1- } \\
689\end{array}$ \\
\hline $\begin{array}{l}\text { Metalurgia básica e fabricação de produtos em } \\
\text { metais }\end{array}$ & $\begin{array}{l}\text { S1-671; S1-672; S1-673; S1-674; S1-675; S1-676; S1-677; S1- } \\
\text { 678; S1-679; S1-691; S1-693; S1-694; S1-695; S1-696; S1-698 }\end{array}$ \\
\hline Fertilizantes & S1-271; S1-561 \\
\hline Produtos Químicos & $\begin{array}{l}\text { S1-431; S1-512; S1-513; S1-514; S1-521; S1-531; S1-532; S1- } \\
\text { 533; S1-541; S1-551; S1-553; S1-554; S1-571; S1-581; S1-599 }\end{array}$ \\
\hline $\begin{array}{l}\text { Máquinas e Equipamentos (inclusive maq. para } \\
\text { escritório) }\end{array}$ & $\begin{array}{l}\text { S1-692; S1-697; S1-711; S1-712; S1-714; S1-715; S1-717; S1- } \\
718 ; \text { S1-719; S1-951 }\end{array}$ \\
\hline Material Elétrico e de comunicações & S1-722; S1-723; S1-724; S1-725; S1-726; S1-729 \\
\hline Equipamentos de Transporte & S1-731; S1-732; S1-733; S1-734; S1-735 \\
\hline Produtos Diversos & $\begin{array}{l}\text { S1-351; S1-663; S1-667; S1-812; S1-861; S1-862; S1-863; S1- } \\
\text { 864; S1-891; S1-892; S1-894; S1-895; S1-896; S1-897; S1-899; } \\
\text { S1-931; S1-961 }\end{array}$ \\
\hline
\end{tabular}


Mudança estrutural e crescimento sob restrição externa na economia brasileira

Quadro 2

Resumo da Nova Classificação

\begin{tabular}{|c|c|}
\hline Setores & Exemplos de Produtos \\
\hline $\begin{array}{l}\text { Alimentos, brutos e processados, Animais } \\
\text { Vivos, Bebidas e Fumo }\end{array}$ & $\begin{array}{l}\text { sFrutas, Carnes, Bebidas, Óleos e Gorduras, Café, Cacau, Açúcar, } \\
\text { Especiarias, Tabaco, Animais Vivos, Comidas Preparadas, etc. }\end{array}$ \\
\hline Madeira, Produtos em Madeira e Mobiliário & $\begin{array}{l}\text { Madeira Bruta e Trabalhada, Cortiça, Manufaturas em Madeira e } \\
\text { Cortiça, Móveis }\end{array}$ \\
\hline Artigos de Borracha e Plástico & $\begin{array}{l}\text { Borracha Bruta, Materiais de Borracha e Plástico, Artigos em } \\
\text { Geral de Borracha e Plástico }\end{array}$ \\
\hline Papel e Celulose & Pasta e Resíduos de Papel, Papelão, Artigos de Papel e Papelão \\
\hline Têxtil & $\begin{array}{l}\text { Seda, Lã, Algodão, Juta, Fios e Tecidos, Rendas e Bordados, } \\
\text { Tapeçaria, etc. }\end{array}$ \\
\hline Vestuário, couros e calçados & $\begin{array}{l}\text { Manufaturas de Couro, Roupas, Calçados, Artigos de Viagens, } \\
\text { Bolsas e Artigos Similares, Roupas de Pele, etc. }\end{array}$ \\
\hline $\begin{array}{l}\text { Fabricação de Produtos de Minerais Não } \\
\text { Metálicos }\end{array}$ & $\begin{array}{l}\text { Cal, Cimento, Argila, Vidro, Artigos de Vidro, Artigos de } \\
\text { Cerâmica, Materiais de Construção de Argila e Refratários }\end{array}$ \\
\hline $\begin{array}{l}\text { Coque, Petróleo, Elaboração de Combustíveis } \\
\text { Energia }\end{array}$ & $\begin{array}{l}\text { eque, Petróleo, Derivados do Petróleo, Gás Natural e } \\
\text { Manufaturado, Urânio e Tório e suas Ligas, Materiais Radioativos } \\
\text { e Energia Elétrica }\end{array}$ \\
\hline Extração de Minerais metálicos não ferrosos & $\begin{array}{l}\text { Minério e Concentrados de Metais Não Ferrosos, Dejetos de } \\
\text { Metais Não Ferrosos, Prata e Metais de Platino, Minerais e } \\
\text { Concentrados de Tório e Urânio }\end{array}$ \\
\hline $\begin{array}{l}\text { Extração de Minerais, exceto metálicos } \\
\text { não ferrosos }\end{array}$ & $\begin{array}{l}\text { Pedra, Areia, Cascalho, Enxofre, Abrasivos Naturais, Minério de } \\
\text { Ferro e Concentrados, Dejetos de Ferro e Aço }\end{array}$ \\
\hline Metalurgia básica de não ferrosos & $\begin{array}{l}\text { Cobre, Níquel, Alumínio, Zinco, Chumbo, Estanho, Prata e Metais } \\
\text { do Grupo Platino, etc. }\end{array}$ \\
\hline $\begin{array}{l}\text { Metalurgia básica e fabricação de produtos em } \\
\text { metais }\end{array}$ & $\begin{array}{l}\text { Fundição, Tubos, Canos, Arames, Trilhos, Ferramentas de Uso } \\
\text { Manual ou em Máquinas, Cutelaria, Lingotes e Barras de Aço } \\
\text { Fundido, Laminados de Aço e Ferro, etc. }\end{array}$ \\
\hline Fertilizantes & Fertilizantes em Bruto e Manufaturado \\
\hline Químicos & $\begin{array}{l}\text { Produtos Químicos Orgânicos e Inorgânicos, Corantes e } \\
\text { Pigmentos, Produtos de Perfumaria, Produtos Explosivos e de } \\
\text { Pirotecnia, Materiais Plásticos e Resinas, etc. }\end{array}$ \\
\hline $\begin{array}{l}\text { Máquinas e Equipamentos (inclusive maq. pa } \\
\text { escritório) }\end{array}$ & $\begin{array}{l}\text { Motores, Maquinaria Agrícola, Máquinas para Escritório, } \\
\text { amaquinaria para Têxteis e Couros, Armas de Guerra e Munição, } \\
\text { Maquinaria e Aparatos para Partes Não Elétricas, Máquinas para } \\
\text { Trabalhar Metais, etc. }\end{array}$ \\
\hline Material Elétrico e de comunicações & $\begin{array}{l}\text { Máquinas de Força Elétrica, Equipamentos para Distribuição } \\
\text { Elétrica, Aparelhos de Telecomunicações, Equipamentos Elétricos } \\
\text { de Uso Doméstico, Aparelhos Elétricos para Medicina e } \\
\text { Radiologia, etc. }\end{array}$ \\
\hline Equipamentos de Transporte & $\begin{array}{l}\text { Veículos para Ferrovias, Veículos Automotores, Aeronáutica, } \\
\text { Navios e Barcos }\end{array}$ \\
\hline Produtos Diversos & $\begin{array}{l}\text { Artigos de Escritório, Joias, Acessórios Sanitários, para Calefação } \\
\text { e Iluminação, Instrumentos de Científicos de Medição, Óticos, } \\
\text { Médicos e de Controle, Aparatos Fotográficos e Cinematográficos, } \\
\text { Impresso, Relógios, Instrumentos Musicais, etc. }\end{array}$ \\
\hline
\end{tabular}

Fonte: Elaboração própria. 